\title{
Öğretmenlerin Mesleki Gelişimi Üzerine Kavramsal Bir Çerçeve ve Türk Eğitim Sistemi İçin Çıkarımlar
}

\author{
Abdurrahman ILĞAN'
}

\begin{abstract}
Öz: Öğretmenler günümüz dünyasında son derece önemli ve etik bir meslek icra etmektedirler. Öğretmenler, nitelikli, etik ve yüksek standartlarda hizmet sunabilmek için diğer profesyoneller gibi mesleki gelişim faaliyetlerine katılırlar. Günümüz dünyasında fevkalade miktarda bilgi üretimi söz konusu olup, öğretmenlerin güncel olması için mesleki gelişim faaliyetlerine katılımları gereklilik arz etmektedir. Derleme niteliğine sahip bu çalışmada, mesleki gelişim kavramı ve önemi, mesleki gelişim faaliyetlerini etkili kılan nitelikler, günlük öğretim işinin içerisinde ve işiçinde mesleki gelişim yaklaşımları olan mentorluk ve akran koçluğu ile ders çalışması ve Şangay araştırma takımları tartışılmıştır. Bu makalenin özgün katkısı ise, etkili mesleki gelişim sisteminin kurulması amacıyla destekleyici bazı unsurlara ilişkin çıkarımların ardından, mesleki gelişimi etkili kılan unsurlara yönelik Türk eğitim sistemi için çıkarım ve tartışmalar yapılmış olmasıdır.
\end{abstract}

Anahtar Sözcükler: Mesleki Gelişim, Koçluk, Mentorluk, Öğretmen, Etkili Mesleki Gelişim

\section{A Conceptual Frame about Professional Development of Teachers and Implications for Turkish Education System}

\begin{abstract}
Teachers fulfil quite important and ethical job in a modern era. Teachers participate professional in development opportunities like other professionals to deliver sufficient, ethical, and high-quality service. Current world produces enormous knowledge that teachers needed participate in professional development activities to be updated. Non-empirical this study included professional development and its importance; features that ensure professional development effective; job-embedded professional development opportunities managed as daily part of job such as mentoring, peer coaching, lesson study and Shanghai research and lesson groups along with conclusions. The authentic contribution of this study was implications about features that champion professional development effective for Turkish educational system along with inferences about creating way of for an effective professional development system that will support teachers and learners.
\end{abstract}

Keywords: Professional Development, Coaching, Mentoring, Teacher, Effective Professional Development

1 İzmir Demokrasi Üniversitesi, Eğitim Fakültesi, Eğitim Bilimleri Bölümü, İzmir, Türkiye e-posta: abdurrahman.ilgan@idu.edu.tr, ORCID: https://orcid.org/0000-0002-2972-7727 
Eğitim faaliyetleri, insanoğlunun yeryüzüne ayak basmasından birinci sanayi devrimine kadar, örgün eğitime ihtiyaç duyulmaması sebebiyle, ağırlık olarak informal şekilde, aile veya sosyal çevre içerisinde yürütülmüştür. Sanayi devrimi sonrası ise toplumun ve ekonomik üretim mekanizmalarının hızla değişmesi sonucu, çok sayıda insanın çalışmaya başladığı ve mekanik hale gelmiş işyerleri ile fabrikalarda, nitelikli insan gücü ihtiyacı ortaya çıkmıştır. Bu ihtiyaç okul veya okul çatısı şeklinde tanımlanan ve ağırlıklı nüfuzlu ailelerin çocuklarının eğitim gördüğü örgün eğitim sistemlerini kitleselleştirmiş, ardından da ilköğretim çağındaki çocukların okullara devamı, aynı zamanda bireyin hakkı olarak, yasal güvenceler altına alınmıştır. Küreselleşmenin yanında hızlı değişim ve dönüşümün yaşandığı günümüz dünyasında, genç nesillerin 21 . yüzyılda ihtiyaç duyduğu bilgi ve becerilerin elde edilmesi noktasında örgün eğitim sistemine büyük görevler düşmekte ve buna ilişkin bireylerin, ailelerin, toplumun ve kamuoyunun beklentileri gittikçe artmaktadır. Eğitim sisteminin bilişsel çıktıları, Türkiye ve dünyada merkezi sınavlarla ölçülmekte ve bu sınavlarda elde edilen sonuçlara göre, kamuoyunda beklenti ve baskılar oluşmaktadır. Eğitim çıtıları üzerinde hangi faktörlerin etkili olduğu üzerinde on yıllardır yapılan araştırmalarda öğretmen faktörünün hemen en etkili unsur olduğuna ilişkin çeşitli araştırma bulguları mevcuttur (Archibald, Coggshall, Croft ve Goe, 2011; Darling-Hammond, 2000). Eğitim çıktılarında son derece önemli bir figür olan öğretmenin hizmet öncesinde aldığı eğitimin düzeyi de öğretim niteliği üzerinde önemli bir etkiye sahiptir (İlğan, 2014). Ekonomik Kalkınma ve İşbirliği Örgütü (Organization for Economic Co-operation and Development [OECD])'nün (2019) 48 ülkede öğretmenler ve okul müdürleri üzerinde 2018 yılında yaptığı Uluslararası Öğrenme ve Öğretme Araştırması'nda (Teaching and Learning International Survey [TALIS]), tüm ülkelerde katılımc1 öğretmenlerin $\% 50$ 'sinin en yüksek eğitim düzeyi olarak lisans düzeyinde eğitime sahip oldukları; Türkiye'nin de dahil olduğu 13 ülkede ise öğretmenlerin \%75'inin sahip oldukları en yüksek eğitim düzeyi olarak lisans düzeyi olduğu ortaya çıkmıştır. OECD ülkelerinde araştırmaya dahil olan öğretmenlerden lisansüstü eğitime sahip öğretmen oranı \%45.5, Türkiye'de ise bu oran \%7.1 şeklinde; Milli Eğitim Bakanlığ1 (MEB)'nın (2019a) faaliyet raporunda ise lisansüstü eğitime sahip personel oranı ise \%9.07 şeklinde ortaya çıkmıştır. Öğretmenlik mesleğinde lisans düzeyindeki eğitimin öğretim faaliyetlerinin karmaşık bir duruma dönüşmüş olması, gittikçe artan kamuoyu baskı ve beklentisinin yanında, ilgi, ihtiyaç ve beklentileri oldukça farklı ve çeşitli olan öğrencilere nitelikli yaşantılar sunmak için yeterli olmadığını ifade etmek mümkündür. Nitekim TIMSS (Trends in International Mathematics and Science Study) 2015 sinavina katılan 8. sinıf Türk öğrencilerinin matematik ders başarısının yordanmasına ilişkin yapılan araştırmada, 12 bağımsız değişken arasında, öğretmenin eğitim düzeyinin üçüncü sırada açıklayıcı olduğu; bunun yanında fen başarısında birinci olan Singapur'da ise lisansüstü eğitime sahip öğretmenlerin öğrencilerinin, lisans eğitimine sahip öğretmenlerin öğrencilerinden daha başarılı olduğu ortaya çıkmıştır (Özkan, 2019). Bu noktada, lisans programına oranla, daha güçlü bir uzmanlık ve karmaşık içerik sunan lisansüstü eğitim düzeyine sahip olduğunu açıklayan öğretmen oranının \%75'in üzerinde (OECD, 2019) olduğu, Hırvatistan, Çek Cumhuriyeti, Finlandiya, Gürcistan, İtalya, Portekiz ve Slovakya' daki öğretmenlerin mesleğe daha hazırlıklı başladıklarını ifade etmek mümkündür.

Öğretmen performansında ve öğrenme çıtılarında hizmet öncesi eğitimin temel bileşenleri olan, alan bilgisi, pedagojik formasyon bilgisi ve genel kültür bilgisinin önemi yadsınmamakla birlikte; bunların tek başına performans için yeterli bir gösterge olmaktan uzak olduğunu ifade etmek mümkündür (İlğan, 2014). Öğretmenin performans ve başarısında, ifade edilen mesleki bilişsel yeterliklerin yanında, öğretmenliğin beceri kısmını ifade eden sanatsal kısmı da oldukça büyük öneme sahiptir. Sahne sanatçısının, sahnedeki performansının icra ettiği sanatın başarısının doğrudan bir göstergesi olması gibi, öğretmen de bir tür sahne sanatçısı olarak, sınıf ortamında sergilediği davranışların, onun iş başarısı üzerinde etkisi vardır. Öğretmenlik mesleğinin sanatsal kısmı ağırlıklı olarak, sınıfı yönetme becerisi ile tanımlanmış sekiz zekâ türünden birisi olan duygusal ve sosyal zekasını uygulamaya aktarma becerisine dayanmakta olup, bunlara ilişkin göstergeleri şu şekilde tanımlamak mümkündür: a) Öğrencilere ilham ve yaşam enerjisi verme, b) öğretim süreci boyunca öğrenci motivasyonunu sağlama, c) derslerini eğlenceli ve esprili bir şekilde işleyebilme, d) mesleğini tutku ve heyecanla icra etme, e) istenmeyen davranışlara ortaya çıkış şekli, yoğunluğu ve bağlamına göre uygun stratejilerle müdahale etme, f) öğrenci dikkatinin dağıldığı zaman, yapacağı kısa, sürpriz ve beklenmeyen etkinliklerle dikkatleri tekrar toplayabilme, viii) derslikte, ne zaman nerede ve ne sürede 
bulunması gerektiği, iv) hangi öğrenciler ile göz teması kurması ve kimlere söz hakkı vermesi gerektiği ve v) sesinin şiddet ve tonunu dersin akışına göre kullanabilmek gibi oldukça geniş bir beceri repertuarını kapsamaktadır. Belirtilen yetilerin birçoğu uygulama gerektiren beceriler olup, öğretmenlerin belirtilen alanlarda ustalaşması için hizmet içinde nitelikli mesleki gelişim faaliyetlerine ihtiyaçları vardır.

Barber ve Mourshed'in (2007) matematik ve fen okuryazarlığında yüksek (İngiltere, Singapur, Finlandiya ve Amerika Birleşik Devletleri (ABD)'nin Boston eyaleti) ve düşük performans gösteren ülke öğrencilerinin akademik performanslarından elde ettikleri kanıt; öğrenme çıtıları üzerinde sürdürülebilir ve önemli ilerlemelerin sunulmasının en etkili yolunun, öğretim üzerinde sürdürülebilir ve işe yarar ilerlemeler yoluyla sağlanabileceğidir. Bunu sağlamanın yolu da öğretmenin mesleki gelişimini sağlamaktan geçtiğini ifade etmek mümkündür. Yine mesleki gelişim, küresel bağlamda eğitim çıtılarının artırılmasına ilişkin baskılarda milli eğitim sistemlerinin yenilenmesi ve reform çabalarında gittikçe artan anahtar bir öneme sahiptir (Hardy, 2012).

Bunların yanı sıra günümüzün teknoloji dünyasında çok büyük bilgi üretimi söz konusudur. Gelecek bilimci ve kâş̧if Fuller (1982), 1900 yılına kadar insanlığın ürettiği bilginin 100 yılda bir ikiye katlandığını, 1945 yılında her 25 yılda bir ikiye katlandığını ve 1982' de ise bu sürenin 12-13 aya indiğini belirtmiş olup; IBM'nin (akt. Rosenberg, 2017) öngörüsünde ise bilginin katlanma süresinin 2020'de 11-12 saate düşeceği şeklindedir. Bu kadar hızlı bilgi üretiminin olduğu bir dünyada, profesyonel çalışanlar olan öğretmenlerin mesleki gelişim faaliyetlerinin yaşam boyu devam etmesi önem arz etmektedir. Öğretmenlere yönelik mesleki gelişim faaliyetlerini konu edinen ampirik olmayan bu araştırmada (Cropanzano, 2009) mesleki gelişim kavramı ve önemi, yüksek nitelikli mesleki gelişimin sahip olduğu nitelikler; işiçinde mesleki gelişim faaliyetleri olarak değerlendirilen ve oldukça etkili yaklaşımlar olan mentorluk, koçluk ve ders çalışması ve bunlar arasındaki benzerlik ve farklılıklar; mesleki gelişim faaliyetlerinde karşılaşılan zorluklar; Türkiye ve dünya ülkelerinde mesleki gelişim faaliyetlerine katılım süreleri ve son kısımda ise ampirik araştırmalar ve alanyazın temelinde, öğretmenler için mesleki gelişimi destekleyen ve etkili kılan unsurlara ilişkin temel ilkeler ve bu ilkelerin Türk eğitim sistemi için değerlendirilmesi ve buna ilişkin tartışmalara yer verilmiştir.

\section{Mesleki Gelişim Kavramı ve Önemi}

Mesleki Gelişim (MG), öğretmenin hizmet içinde, öğrenme çıtılarını artırmak, öğretim işini daha nitelikli hale getirmek ve öğretim süreçlerinin iyileştirmesi amacıyla yapmış olduğu formal ve informal öğrenme, deneme, gelişme ve ilerleme faaliyetlerini kapsayan oldukça geniş bir kavramdır. MG, OECD (2014, s. 526) raporunda, "öğretmen olarak (daha geniş kapsamda bir profesyonel) bireyin beceri, bilgi ve uzmanlığını geliştirmek amacıyla tasarlanan faaliyetler"; bir başka tanımda ise, "öğretmenlerin mesleki çalışmalarını ilerletmek amacıyla tasarlanmış ve kariyeri süresince katıldığı tüm faaliyetler" şeklinde tanımlanmıştır (Day ve Sachs, 2004; akt. Hardy, 2012). Öğretmenin mesleki öğrenmesi karmaşık bir süreç olup, öğretmenlerin bireysel ve müşterek şekilde bilişsel ve duygusal katılımını gerektirmekte, fikir ve görüşler bağlamında her öğretmenin durduğu yere ilişkin kapasitesinin ve gönüllülüğünün incelenmesinin yanında, ilerleme ve değişim için uygun alternatiflerin dikkatle incelenmesi ve düzenlenmesini ifade etmektedir. Tüm bunlar ise belirli eğitim politikaları veya okul kültürlerinde meydana gelmekte olup, bunların bazıları diğerlerine oranla öğrenme için daha uygun koşul ve olanaklar sağlamaktadır (Avalos, 2011). Dünyada ulusal hükümetler, nitelikli eğitim-öğretim ile öğrenci öğrenmesi ve artırılmış öğrenme çıktılarını kolaylaştırmanın yolu olarak MG faaliyetlerini teşvik etmektedirler (Hardy, 2012). OECD (2005) raporunda hizmet öncesi eğitimin, öğretmenlik mesleğine ilişkin temelleri oluşturmakla birlikte, sürekli MG'nin işgücünün gelişimi ve her daim etkin olmasına hizmet edeceğini; bu tür faaliyetlerin, öğretmenlerin bilgilerini tazeleme, geliştirme, genişletme ve öğretimi anlamaları ile beceri ve uygulamalarını ilerletmelerine katkı sağlamasının yanı sıra; öğretmenlerin oryantasyonunu (uyumunu) ve hizmet öncesinde yetkin şekilde verilmeyen eğitimin telafi edilmesini kolaylaştıracağını belirtmiştir.

Terfi, maaş artışı, özlük hakları gibi diş motivasyon ve maddi unsurlar öğretmenlerin MG faaliyetlerine katılımını teşvik etmekte başarılı olmakla birlikte, bunların MG yetiştirmelerinin anlamını özünden çıkarıp, sadece iş durağanlığına / sıradanlaştırmaya dönüştürme riski mevcuttur. Öğretmenlerin MG faaliyetlerine 
katılımları maddi unsurların yanı sıra; öğretmenler arasında öğrencilerini desteklemek ve yardım etmek amacıyla becerilerini geliştirmeye (Scribner, 1999) ve -başkaları ve toplum yararına iyi bir şey yapmaya ilişkinkamu yararı motivasyonu (Perry, Hondeghem ve Wise, 2010) gibi öğretmenin bağlılı̆̆ını artıran ve görevlerine odaklanmasını da sağlayan içsel motivasyon kaynaklarını da eklemek mümkündür. İş çıktılarının bütünsel anlamda birilerinin ve toplumun ilerlemesi üzerinde etkileri olduğu algısına sahip çalışanların, yüksek düzey kamu hizmeti sergileme motivasyonları, yapmakta oldukları işin niteliğini iyileştirmek amacıyla daha fazla çaba sergilemede istekli hale gelmelerini sağlamakta (Perry ve Wise, 1990) olup; bu saikle hareket edenlerin, işinin niteliğini artırmak amacıyla MG faaliyetlerine doğrudan bir zorlama olmaksızın katılımı beklenen olası bir durum olacaktır. OECD (2019) ülkelerinin hemen tamamında -Alberta (Kanada), Suudi Arabistan ve Güney Afrika hariç- öğretmenlerin karakteristik özellikleri kontrol altına alındıktan sonra, mesleğin tercih edilmesinde önemli unsur olan -öğretmenlik mesleğinde kamu yararı görme ile gençleri ve toplumu bilinçlendirme ülküsünü ifade eden- "sosyal yararlılı" indeksi yüksek olan öğretmenlerin, MG faaliyetlerine daha fazla katılma eğiliminde oldukları ortaya çıkmıştır.

Eğitimcilerin günümüzde, önceki yıllara ve zamana göre daha fazla öğrenmeye ihtiyaçları olmasından dolayı, mesleki öğrenmenin yerini mesleki gelişim almıştır. Gelişim yeterli olmayıp, eğitimcilerin bilgili ve akıllı olmanın yanında, değişim için yeterli bilgi sahibi olmaları gerekmektedir. Öğretmenlerin farklı sonuçlar almaları için, değişmeleri, öğrenici olmaları ve kendi gelişimlerini sağlamaları gereklidir (Easton, 2008). ABD'de ulusal düzeyde alınan bir örneklem üzerinde yapılan araştırmada, katılımcı öğretmenlerin büyük çoğunluğu, mesleki gelişimin iyileştirilmesinin, öğretmenin etkililiğini artıracağı görüşünde olduklarını ortaya koymuştur (Coggshall ve Ott, 2010). Dünyanın herhangi bir yerinde yüksek performans gösteren okulların liderleri, okul geliştirmenin odak noktasının, öğretmenlerin öğrencilere sundukları öğretim yolunu / yöntemini farklılaştırma odaklı öğretmen davranışını değiştirmek, diğer bir deyişle geliştirmek, olduğunu bilirler (Jensen, 2012). OECD (2019) ülkelerinde öğretmenlerin \%55'i kendilerine yüksek nitelikli MG faaliyetleri sunulmasının oldukça önemli olduğu şeklinde görüş beyan etmek suretiyle, MG'nin önemi konusunda farkındalık sahibi oldukları çıkarımında bulunmak mümkündür. Craft (2002), MG faaliyetlerinin yürütülmesini elde edilen kazanımlar kapsamında şu gerekçelerle açıklamaktadır:

- Bir grup veya tüm personelin iş performansı becerilerini iyileştirmek,

- Bireysel olarak bir öğretmenin iş performansı becerilerini iyileştirmek,

- Kariyer gelişimi veya terfi sağlamak amaciyla bireysel olarak öğretmenin deneyimini büyütmek,

- Bireysel olarak öğretmenin mesleki bilgi ve kavrayışını geliştirmek,

- Personeli daha fazla tatmin etmek ve iş doyumu sağlamak,

- İşe ilişkin daha geniş bir yaklaşım geliştirmek,

- Öğretmenlerin değişime hazır ve proaktif olmalarını sağlamak.

Jensen ve Farmer (2013), 2009 yılında yapılan PISA (Programme for International Student Assessment) sınavında Matematik ve Fen alanında dünya birincisi olan Çin'in Şangay bölgesinin -2018 tarihli PISA sınavında ise her üç alanda da Çin'i temsilen birinci olmuştur- ciddi başarı elde etmesinde şu beş unsur üzerinde yaptığı değişimin etkili olduğunu belirtmişlerdir: 1) Öğrenci ve öğretmenin beklentilerini artıran stratejik planlama ve okul liderliği, 2) öğrenci öğrenmesini destekleyen ve geliştiren okul kültürü, 3) mesleki işbirliğini vurgulayan etkili öğretim, 4) öğrenci öğrenmesi ve etkili öğrenme davranışlarının ölçümü ve geliştirilmesi ve son olarak da 5) öğrenci öğrenmesini teşvik eden güçlü topluluk ilişkileri. Üçüncü bileşen olan "etkili öğretim" MG ile ilişkili olması dolayısıyla yazarlar tarafından şu şekilde açıklanmıştır: “Dünya ülkelerinde başarısı düşük okulların başarı noktasında dönüşümünü sağlama amacıyla, öğrencileri öğrenmeye iten şeyler öğretimin geliştirilmesidir. Uygun MG ve mesleki öğrenme eğitimcileri, okulun odak noktasıyla uyumlu öğrenci ihtiyaçlarına hitap eden pedagojik yaklaşımlarla donamalarını sağlar.".

Şangay'la beraber Hong Kong, Kore ve Singapur'un yer aldığı ve PISA 2009'da üstün başarı gösteren (Örneğin: Şangaylı öğrencilerin matematik bilgi düzeyi; ABD, Avustralya, Birleşik Krallık ve 21 AB [Avrupa Birliği] ülkesindeki yaşıtlarından iki ile üç yıl arasında öndedir.) ülkelerin MG bağlamında başarılarına katkı sağlayan şu bileşenlerden bir veya birkaçına sahiptirler (Jensen, 2012): 
- Hizmet öncesi öğretmen eğitimi yüksek nitelikli olarak verilir. Singapur'da eğitim fakültesi öğrencilerine memur gibi yüksek burs ödemesi verilmektedir. Kore'de hükümet öğretmen eğitim konusunda sıkı düzenlemelere sahip olup, niteliği düşük öğretmen eğitim kurslarını kapatabilmektedir.

- Öğrenme ve öğretimi mütemadiyen iyileştiren mentorluk hizmeti sunulmaktadır. Şangay'da tüm öğretmenlerin mentoru mevcut olup, meslekte yeni olan aday öğretmenlerin ise, derslerini gözleyen ve onlara geri bildirim veren birden çok mentorleri vardır.

- Öğretmenleri araştırmacı olarak görürler. Öğretmenler, Şangay’da süreğen şekilde yenilikçi öğretim uygulamalarını geliştirme ve değerlendirme çalışmaları yapan gruplarda çalışırlar. Yine öğretmenlerin, hakem denetiminden geçmiş araştırma makalesi yayınlanmadan, kariyer basamaklarında ilerleme imkanları yoktur.

- Mentorluk ve meslektaş koçluğunun temel bileşeni de olan ders gözlemleri yaparlar. Öğretmenler düzenli olarak birbirlerinin derslerini gözler ve her bir öğrencinin öğrenmesini iyileştirmek amaciyla, dersin hemen ardından geri bildirim verirler.

- Etkili (başarılı) öğretmenler terfi ettirilmekte ve onlara öğretme ile öğretim konusunda daha fazla sorumluluk verilmektedir. Usta (uzman) öğretmenlere, eğitim sisteminde öğretimin iyileştirilmesi için sorumluluk verilmektedir.

Merkezi sınavlarda başarı gösteren ülkelerin MG'ye yönelik ilkeleri incelendiğinde; MG faaliyetlerinin kısa süreli etkinlikler yerine- süreklilik arz ettiği, öğretmenlere yasal çalışma saatleri içerisinde faaliyetleri gerçekleştirmek için zaman tahsis edildiği, öğretmenlerin ihtiyaçlarının dikkate alındığı ve faaliyetlerin planlanmasında katılımlarının sağlanmasının yanında, aday öğretmenlere mentor ataması yapıldığı ve mentorlere bununla ilgili eğitim verildiği görülmektedir. Şangay eğitim sistemi, diğer dünya ülkelerinin eğitim sistemleriyle karşılaştırıldığında, akademik başarının artışında önemli etkisi olduğu varsayılan öğretmen çalışmasına ilişkin yatırım yaptıkları şu dört unsurun $\mathrm{MG}^{\prime}$ ye verdikleri önemin bir göstergesi olduğunu ifade etmek mümkündür. Bunlar (Jensen ve Farmer, 2013): a) mesleki işbirliği, b) mesleki öğrenme, c) oryantasyon (mesleğe entegrasyon) ve mentorluk ile d) Japonya' da da yaygın şekilde kullanılan, aşağıdaki başlıklarda ayrıca açıklanan, araştırma ve çalışma gruplarıdır. İfade edilen unsurların Şangay ve Japon eğitim sistemlerinin uluslararası sınavlardaki başarısında ve dolayısıyla bilim ve teknoloji alanındaki ilerlemelerinde önemli katkısı olduğu ifade edilebilir.

Öğretmenlik mesleğinin eğitimli ve nitelikli gençler tarafından yeterince tercih edilmediği, mesleğin ilk yıllarında işgören devrinin yüksek olduğu ve Gayrisafi Yurtiçi Hasılanın yüksek olduğu ABD ile Avrupa ülkelerinde, yüksek nitelikli MG'nin, mesleki kariyerinin başındaki öğretmenlerin işte kalması yani işine devam etmesi üzerinde (Allensworth, Ponisciak ve Mazzeo, 2009) ve birçok öğretmenin çalışmayı tercih etmediği dezavantajlı okullarda çalışmaya devam etmeleri (Coggshall ve Ott, 2010) üzerinde olumlu etkileri vardır. MG kavramı ve öneminden sonra MG'yi etkili kılan, yüksek nitelik kazandıran özellikler aşağıda tartışılmıştır.

\section{Mesleki Gelişimi Etkili Kılan Nitelikler}

İşgörenlere yönelik nitelikli, işe yarayan, personel verimini artıran MG faaliyetleri sunulması, kamu ve özel sektör örgütleri için önem arz etmekle birlikte kendi içinde çeşitli zorlukları da barındırmaktadır. Personeli hizmet içinde yetiştirmeye yönelik MG faaliyetlerinin verimi artırma, personel moralini yükseltme, kariyer gelişimini sağlama ve işgören devrini düşürme gibi birçok yararının yanında; özellikle öğretmenlerde işe yarar nitelikli faaliyetlerin planlanması, yürütülmesi ve sonuçlarının değerlendirilmesine ilişkin güçlükler mevcuttur (Craft, 2002). Mesleki gelişime olan ilgili artmakla birlikte, öğrenci başarısı üzerinde olumlu etkisi hakkında tartışmalar devam etmekte (Song, Hur ve Kwon, 2018) olup, mesleki gelişimin hangi karakteristik özelliklerinin öğrenci çıktıları üzerinde ne düzeyde etkisi olduğuna ilişkin kanıtların yeterli olmadığı (Garet, Porter, Desimone, Birman ve Yoon, 2001) belirtilmiştir. İlgili konuda öncü araştırmaları inceleyen Guskey (2003) ve Knapp (2003) da ortak karakteristik özellikler konusunda yeterli uzlaşı olmadığı görüşüne sahip olmakla birlikte; iki binli yıllardan günümüze geçen süre içinde, MG faaliyetlerinden hangi unsurların onları etkili kıldığına ilişkin çok sayıda araştırma yürütülmüş ve bunlara ilişkin yapılan alanyazın incelemesi 
Öğretmenlerin Mesleki Gelişimi Üzerine...

sonucunda; bu çalışma kapsamında Türkiye'nin sosyal, kültürel, ekonomik ve politik koşulları bağlamında Türk eğitim sistemine yönelik tartışma ve çıarımlar yapılmaya çalışılmıştır.

Etkili mesleki gelişim, paydaşların özellikle de zümre öğretmenlerin işbirliği, katılımı ve tartışmalarının sonucunda ortaya çıkmaktadır (Blandford, 2001). Meslektaşların işbirliği, MG faaliyetlerinin niteliğini artıran bir durum olmakla birlikte, yapılan bir araştırma (Hord, Rutherford, Huling-Austin ve Hall, 1998) işbirlikli faaliyetlerin olumlu çıtılar sağlaması için öğretmenlerin çatışma çözme, problem çözme stratejileri, uzlaşı sağlanması ve diğer toplantı becerilerinin geliştirilmesi gerektiğini ifade etmektedir. Hemşireler, mühendisler ve pilotlar gibi bilgi temelli mesleklerin yanında, sıhhi tesisatçı, kuaför ve aşçı gibi beceri temelli zanaatçılar gibi uygulamacıların meslektaşlarıyla işbirliği yapmak suretiyle, öğrendikleri becerilerini geliştirdikleri ve en iyi uygulamalara dair bilgilerini paylaştıklarına ilişkin çok sayıda kanıt mevcuttur (DeMonte, 2013). Hem OECD (2019) ülkelerinde hem Türkiye'de, öğretmenlerin son bir yıl içerisinde katıldığı MG faaliyetlerinin işbirlikli öğrenme fırsatları sağladığını belirten öğretmen oranı, birbirine yakın oranlarda, \%74 şeklinde ortaya çıkmıştır. Bu sonuca göre, Türkiye'de ve dünya ülkelerinde öğretmenlere sunulan MG etkinliklerinin, faaliyetleri etkili kılan işbirlikli öğrenme fırsatlarını, görece yüksek düzeyde içerecek şekilde sunulduğu sonucuna ulaşmak mümkündür.

Öğretmenlere yönelik yürütülen MG faaliyetlerinin, öğretmenlerin aktif katılımını sağlamasının etkili bir yaklaşım olduğu ifade edilmektedir (Hawley ve Valli, 1999; Opfer ve Pedder, 2011). OECD (2019) ülkelerinde öğretmenlerin son bir yıl içerisinde katıldığı MG faaliyetlerinin aktif öğrenme fırsatları sağladığını belirten öğretmen oranı \%96.4 iken; Türkiye'den katılan öğretmenlerde ise bu oran \%76.6 şeklinde beyan edilmiştir. Öğretmenler için aktif öğrenme fırsatları; uzman öğretmenlerin öğretimlerini gözlemek, yeni öğretim programı materyallerinin ve yeni öğretim tekniklerinin sınıfta nasıl kullanılacağına ilişkin bir plan yapmak, öğrenci çalışmalarını analiz edip başarıları hakkında çıkarımlarda bulunmak, meslektaşlardan oluşan bir grup tartışmasına liderlik yapmak ve yazılı akademik metinlerden çıkarımlarda bulunmak şeklinde farklı formları içerebilir (Song ve diğerleri, 2018).

MG faaliyetlerinin tasarımında, yetişkin bireyler olan öğretmenlerin, yetişkinlerin nasıl öğrendiğine ilişkin araştırma temelli bilgileri dikkate alınmalıdır. ABD Milli Araştırma Kurumu tarafından organize edilen ve üst düzey bir jüri tarafından yapılan panel değerlendirmesinde yetişkin öğrenmesine ilişkin özetle şu sonuca ulaşılmıştır (Bransford, Brown ve Cocking, 2001): Yetişkinler öğrenme ortamına dünyanın nasıl işlediğine ilişkin hazırbulunuşlukları ile gelirler. Yetişkinler en iyi şekilde öz-yönetimli yani öğrenme faaliyetlerini kendileri yönlendirdiğinde, yeni bilgiyi önceden sahip oldukları bilginin üzerine inşa ettiklerinde, bireysel olarak -kuramsal bilgiyi gerçek durumlara temellendirdikleri- öğrenmelerinin anlam ve öneminin farkında olduklarında öğrenirler. Bunun yanında, öğretime meta bilişsel bir yaklaşımla; kendi öğrenmelerini, hedeflerin tanımlanması ve ardından hedefleri başarma noktasındaki ilerlemelerini gözlemeleri yoluyla kolaylaştırabilir. Benzer şekilde Zepeda (2015) MG faaliyetlerinde dikkate alınması gereken yetişkin öğrenmesinin ilkelerini şu şekilde açılamıştır: a) Yetişkinler neden öğrenmeleri gerektiğini ve elde edecekleri bilginin onların gelişimlerine katkı sağlayacağını bilmek isterler. b) Yetişkinler önceki deneyim ve bilgileri üzerinde hareket etmekte olup yeni öğrenmelerini de bunların üzerine inşa etmektedir. c) Yetişkinler öğrenmeye ne kadar ihtiyaç duyarlarsa, öğrenmek için de o kadar hazır olup, yeni öğrendiklerini hızlıca uygulamaya geçirmek isterler. d) MG faaliyetlerinin planlanmasında paydaşların katılımı ve özyönetime uygunluğu sağlanmalıdır. e) Yetişkinlerin bilgi paylaşımı ve öğrenme noktasındaki bireysel ihtiyaçları, onlarda öğrenmek için itici güç sağlar. f) Hizmet içi eğitim, çalıştay ve seminerlere sıklıkla gönüllü katılanlarda öğrenmeye daha fazla ihtiyaçları olduğu algısı mevcuttur.

1999-2000 öğretim yılında ABD'deki kamu okulları, görev yapan öğretmenlerinin \%95'ine, çalışma saatleri içerisinde MG faaliyetleri için zaman tahsisi sağlamakla birlikte (Choy, Chen ve Bugarin, 2006), Yeni Zelanda'da (Timperley, Wilson, Barrar ve Fung, 2007) ise öğrenci çıktıları üzerinde olumlu etkisi olan öğretmen mesleki öğrenmesi üzerinde etkili olan zaman ve kaynakların yeterince sağlanmadığ1 belirtilmektedir. OECD (2019) ülkelerinde, son bir yıl içerisinde katıldıkları MG faaliyetlerinin etkili olduğunu beyan eden öğretmenler içerisinde, mesleki gelişimi etkili kılan unsurları şu oranlarda ifade etmişlerdir: MG faaliyetlerinin; 1) kendi sınıflarında yeni fikir ve bilgileri uygulama fırsatı sunduğu (\%86), 2) aktif öğrenme 
için fırsatlar sunduğu (\%78), 3) işbirlikli öğrenme için fırsatlar sunduğu (\%74) ve 4) yapmakta oldukları öğretim faaliyetlerinde yeniliğe odaklandığı (\%65). Tüm MG faaliyetlerinin nihai amacının öğrenci öğrenmesi üzerine olumlu etkisi olması beklentisidir. Bu soruya yanıt arayan geniş kapsamlı bir araştırmada (Yoon, Duncan, Lee, Scarloss ve Shapley, 2007) öğretmenin mesleki gelişiminin öğrenci başarısı üzerinde etkisini konu edinen 1300 makale incelenmiş, bunlardan deneysel desende yürütülen yalnızca dokuzunun, doğrudan matematik, fen, okuma becerileri ile anadil ve sanat becerileri başarısılla ilişkisi olması dolayısıyla kapsama dahil edilmiştir. Buna göre, 30 ile 100 saat arasında ve yılın en az yarısı ve tamamı arasına yayılmış olan MG faaliyetlerinin öğrenci başarısının artırılmasında olumlu etkileri olduğu; yılda 49 saat ve üzerinde ve yoğun şekilde sürdürülen MG faaliyetlerinin öğrenci başarısı üzerinde 21 puanlık kazanım sağlamakla birlikte, 5 ile 14 saat arasında sürdürülen faaliyetlerin ise öğrenci öğrenmesi üzerindeki etkilerinin istatistiki olarak anlamlı olmadığı ortaya çıkmıştır. Yurtiçinde 4. sınıf öğrencilerinin katılımcı olduğu ve TIMSS verilerinin kullanıldığı bir araştırmada ise öğrencilerin matematik ve fen başarılarında, öğretmenleri mesleki gelişim faaliyetlerine katılan öğrencilerin puanları ile katılmayan öğretmenlerin öğrencilerinin puanları arasında anlamlı farklılık ortaya çıkmamıştır (Özkan, 2020). Craft (2002), yüksek nitelikli MG faaliyetlerinin teori, modelleme, uygulama, geri bildirim ve koçluk uygulamalarını bütünleştirmesi gerektiğini belirtmektedir. PISA ve TIMSS gibi sınavlarda, öğrencileri yüksek performans gösteren ülkelerde, MG faaliyetlerini karakterize eden ortak özelliklerin şunlar olduğu belirtilmiştir (Wei, Darling-Hammond, Andree, Richardson ve Orphanos, 2009):

- Yoğun şekilde formal ve informal hizmet içi eğitim fırsatları geliştirilmesi,

- Öğretmenlere mesleki öğrenme ve işbirliği için, mesai saatlerinde zaman ayrılması,

- Öğretmenin bağlamı içinde, yani ihtiyaçlarıyla uyumlu ve zaman tahsisi sağlanan mesleki gelişim faaliyetleri,

- Öğretmenlerin öğretim programı ve öğretim uygulamalarına ilişkin kararlarda söz sahibi olmasına imkân verecek okul yönetim yapısı,

- Aday öğretmenlere yönelik mesleki oryantasyon (uyum) programları ve bunu yürütmek için aday öğretmenlere ve mentor öğretmenlere gerekli zaman tahsisi ve mentorlere formal yetiştirme eğitiminin sunulması,

ABD'de Hiçbir Çocuğun Geride Bırakılmaması (No Child Left Behind) Kanunu (2002) yüksek nitelikli mesleki gelişim için beş ölçüt belirlemiş olup bunlar şu şekilde açıklanmıştır:

- Sınıf öğretimi ve öğretmen performansında olumlu ve kalıcı etki bırakması için sürdürülebilir (süreğenlik arz eden), yoğun ve içerik (alan bilgisi temelinde) odaklıdır.

- Eyaletin akademik içerik standartları, öğrenci akademik başarı standartları ve ölçme-değerlendirme ile uyumlu ve doğrudan ilişkilidir.

- Öğretmenin ders verdiği branşındaki bilgisini iyileştirir ve ilerletir.

- Öğretmenin, bilimsel araştırma yöntemleri üzerinde inşa edilen etkili öğretim stratejilerine ilişkin anlayışını ilerletir.

- Öğretmen etkililiği ve öğrenci başarısı üzerine etkileri düzenli olarak değerlendirilir.

Belirtilen kanuna ilişkin MG faaliyetlerinde; alan bilgisi temelinde, bilimsel araştırma yöntemlerinin bulgularından istifade edilen ve eyaletlerin belirlenen standartları ile öğrenci kazanımlarını destekler şekilde planlanması gerektiği anlaşılmaktadır. Öğretmenlere yönelik yürütülen MG faaliyetlerini etkili kılan unsurların başında, bunların öğretmenin günlük öğretim işini icra ettiği zaman ve etkinlikler içinde yani iş içinde yapılmasıdır (Garet ve diğerleri, 2001; Hawley ve Valli, 1999; Opfer ve Pedder, 2011; Wei ve diğerleri, 2009; Zepeda, 2015). MG faaliyetlerinin hangi durumda işiçinde olup olmadığı bilgisinin yanında işiçinde olma düzeyini de gösteren bireysel, karşılıklı ve takım halinde yapılabilecek uygulama örnekleri Tablo 1'de verilmiştir (Croft, Coggshall, Dolan ve Powers, 2010). 
Tablo 1

Bireysel, Karşılıklı ve Takım Halinde Yapılabilecek İşiçinde MG Faaliyeti Uygulama Örnekleri

\begin{tabular}{|c|c|c|c|c|}
\hline & \multicolumn{2}{|c|}{ İşiçinde MG Faaliyetleri } & \multicolumn{2}{|c|}{ İşiçinde Olmayan MG Faaliyetleri } \\
\hline & $\begin{array}{l}\text { Sınıfta, gerçek zamanlı, } \\
\text { sınıfın kendi öğrencileriyle } \\
\text { yürütülmekte olup, } \\
\text { faaliyetin merkezi de } \\
\text { mevcut öğretim } \\
\text { uygulamalarına ilişkin } \\
\text { sorunlardır. }\end{array}$ & $\begin{array}{l}\text { Sınıfta, neredeyse gerçek } \\
\text { zamanlı, öğrencilerin } \\
\text { olmadığı şekilde } \\
\text { yürütülmekte olup, } \\
\text { faaliyetin merkezi de } \\
\text { mevcut öğretim } \\
\text { uygulamalarına ilişkin } \\
\text { sorunlardır. }\end{array}$ & $\begin{array}{l}\text { Okulda, öğretim } \\
\text { uygulamasından hemen } \\
\text { önce veya sonra, } \\
\text { öğrencilerin olmadığı } \\
\text { şekilde yürütülmekte olup, } \\
\text { faaliyetin merkezi de } \\
\text { mevcut öğretim } \\
\text { uygulamalarına ilişkin } \\
\text { sorunlardır. }\end{array}$ & $\begin{array}{l}\text { Okul içinde veya dışında, } \\
\text { öğretim faaliyeti ve } \\
\text { öğrencinin olmadığı } \\
\text { şekilde yürütülmekte olup, } \\
\text { faaliyetin merkezi de } \\
\text { mevcut öğretim } \\
\text { uygulamalarına ilişkin } \\
\text { sorunlardır. }\end{array}$ \\
\hline & $\begin{array}{l}\text { Bir öğretmen, planını } \\
\text { önceden yapmış olduğu } \\
\text { dersi öğrencilerine sınıf } \\
\text { ortamında uygular. Ders } \\
\text { sonunda öğretmenin derse } \\
\text { ilişkin yansıtma yapması } \\
\text { amacıyla, önceden } \\
\text { hazırlamış olduğu sorulara } \\
\text { ilişkin öğrencilerden yazılı } \\
\text { geri bildirim alır. Öğrenci } \\
\text { geri bildirimlerini inceler, } \\
\text { iyileştirilmesi gereken } \\
\text { yönlerini belirler. }\end{array}$ & $\begin{array}{l}\text { Bir öğretmen, planını } \\
\text { önceden yapmış olduğu } \\
\text { dersi öğrencilerine sınıf } \\
\text { ortamında uygularken, } \\
\text { dersini videoya kaydeder. } \\
\text { Ders sonunda öğretmenin } \\
\text { derse ilişkin yansıtma } \\
\text { yapması amacıyla, önceden } \\
\text { hazırlamış olduğu kontrol } \\
\text { listesine göre, derste } \\
\text { planlandığı gibi giden ve } \\
\text { gitmeyen davranış ve } \\
\text { kararlarını not eder, sonraki } \\
\text { derste iyileştirmesi gereken } \\
\text { öncelikli bir hedef belirler. }\end{array}$ & $\begin{array}{l}\text { Bir öğretmen portfolyo } \\
\text { dosyasına eklemek üzere, } \\
\text { odaklanmış olduğu iki } \\
\text { öğrencinin ödev veya } \\
\text { herhangi bir çalışmasını } \\
\text { analiz eder. Bir öğretmen } \\
\text { mesleki bir dergide akıcı } \\
\text { okuma hakkında okuduğu } \\
\text { bir stratejiyi sınıfında } \\
\text { uygular. Buna ilişkin } \\
\text { deneyimi hakkında, online } \\
\text { yayın yaptığı dergisinin } \\
\text { internet günlüğünde } \\
\text { yansıtma yapar. }\end{array}$ & $\begin{array}{l}\text { Bir öğretmen, kanıt-temelli } \\
\text { okuma stratejilerinin } \\
\text { tanımlandığı mesleki dergi } \\
\text { makalesi okur. Fakat ne bu } \\
\text { stratejiyi kendi öğrencileri } \\
\text { üzerinde uygulamaya } \\
\text { ilişkin spesifik anlamlı } \\
\text { fırsatlar bulur ne de bu } \\
\text { stratejiyi sınıfında } \\
\text { uygulamak için yansıtma } \\
\text { yapar. }\end{array}$ \\
\hline 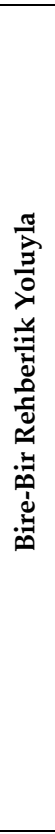 & $\begin{array}{l}\text { Öğretim koçu, zorlu bir } \\
\text { matematik dersi boyunca } \\
\text { öğretmeni gözler; hem } \\
\text { öğretmen hem de } \\
\text { öğrencilerle etkileşim } \\
\text { halinde olur, ders süresince } \\
\text { gereken durumda yararlı } \\
\text { sorular sorar ve öğretmenin } \\
\text { talimatlarını açıklar. Ders } \\
\text { öncesinde, öğretim koçu bu } \\
\text { yöntemi öğretmenle } \\
\text { tartışmış olup, gereken } \\
\text { durumda derse (tartışmaya) } \\
\text { müdahil olmak için onay } \\
\text { almıştır. Bir mentor, aday bir } \\
\text { öğretmenin işlediği dersi, } \\
\text { kapalı devre video } \\
\text { üzerinden senkronize şekilde } \\
\text { izlerken, telefon mikrofonu } \\
\text { yoluyla gerçek-zamanlı } \\
\text { rehberlik sunar. }\end{array}$ & $\begin{array}{l}\text { Bir mentor aday bir } \\
\text { öğretmenle, ders gözlemini } \\
\text { planlamak amacıyla } \\
\text { planlama sırasında ve } \\
\text { gözlem sonrasında görüşme } \\
\text { yapar. Mentor ders } \\
\text { planında ve uygulamasında } \\
\text { güçlü ve zayıf yönlerini } \\
\text { tanımlayarak destekler; } \\
\text { öğretmeni ertesi günkü } \\
\text { dersinde, öğretimine } \\
\text { değişimler yapmaya teşvik } \\
\text { eder. }\end{array}$ & $\begin{array}{l}\text { Bir öğretmen ve onun koçu, } \\
\text { bir gün önce koçun izlemiş } \\
\text { olduğu dersi incelemek } \\
\text { amacıyla toplanırlar; küçük } \\
\text { öğrenci gruplarının nasıl } \\
\text { daha iyi yönetilebileceği } \\
\text { konusunda tartısırlar ve } \\
\text { öğretmen beraber karar } \\
\text { verdikleri bu yeni stratejileri } \\
\text { denemeyi kabul eder. Bir } \\
\text { öğretmen işlemiş olduğu } \\
\text { dersin video klibini, farklı } \\
\text { bir eyalette üniversite } \\
\text { öğretim elemanı olarak } \\
\text { çalışan "sanal eğitmenine" } \\
\text { e-posta ile gönderir. } \\
\text { Öğretmen ve eğitmen video } \\
\text { konferans yoluyla video } \\
\text { klipi tartışır, neyin işe } \\
\text { yaradığını ve nelerin } \\
\text { iyileştirilmesi gerektiği } \\
\text { tanımlanır. }\end{array}$ & $\begin{array}{l}\text { Aday bir öğretmen ve } \\
\text { mentoru, farklı bir okulda } \\
\text { zorluk yaşayan aday bir } \\
\text { öğretmenin örnek olayını } \\
\text { okurlar. Öğretmenler } \\
\text { odasında kendi okulu ile } \\
\text { tasvir edilen örnek olayda } \\
\text { zorluk yaşayan aday } \\
\text { öğretmenin okulu } \\
\text { bağlamındaki benzerlik ve } \\
\text { farklılıkları tartışırlar. } \\
\text { Tartışma, aday öğretmenin } \\
\text { öğretim bilgisine ilişkin } \\
\text { temelini zenginleştirmekle } \\
\text { birlikte, öğretmen için } \\
\text { hemen kullanmak üzere } \\
\text { yapılabilir uygulamalar ve } \\
\text { yansıtma yapma imkânı } \\
\text { sağlamamaktadır. }\end{array}$ \\
\hline 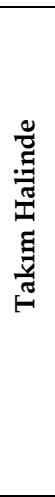 & $\begin{array}{l}\text { Bir öğretim moderatörü } \\
\text { örnek bir ders işler. Bir grup } \\
\text { öğretmen dersi gözler ve } \\
\text { gözlemine ilişkin analiz ve } \\
\text { tanımlamaları içeren notlar } \\
\text { alırlar. Küçük grup } \\
\text { çalışmasında, gözlem yapan } \\
\text { öğretmenler öğrencilerle } \\
\text { neler öğrendikleri hakkında } \\
\text { konuşurlar. Gözlem yapan } \\
\text { öğretmenler, derse katılan } \\
\text { öğrencilerin derslikten } \\
\text { ayrılmasının hemen }\end{array}$ & $\begin{array}{l}\text { Dördüncü sınıf } \\
\text { öğretmenleri gelecek hafta } \\
\text { boyunca uygulamak } \\
\text { amacıyla fen dersi planı } \\
\text { geliştirmek üzere “ders } \\
\text { çalışması” moderatörü ile } \\
\text { toplanırlar. Öğretmenlerden } \\
\text { biri geliştirilen ders planını } \\
\text { gönüllü olarak ilk kendi } \\
\text { sinıfında uygularken, diğer } \\
\text { dördüncü sınıf öğretmenleri } \\
\text { de dersin nasıl gittiğini } \\
\text { gözler. Öğretmenler, ders }\end{array}$ & $\begin{array}{l}\text { Öğretmenler, beraber } \\
\text { çalıştıkları zümre } \\
\text { topluluğunda; öğrencilerinin } \\
\text { sınav sonuçlarını analiz eder } \\
\text { ve öğretimlerinde ihtiyaç } \\
\text { duyulan değişimlerin } \\
\text { yanında ilave destek ve } \\
\text { kaynakları tartışırlar. Bir } \\
\text { öğretmen planlama } \\
\text { döneminde, öğrencilerinin } \\
\text { süreğen akademik başarı } \\
\text { düşüklüğü hakkında farklı } \\
\text { bakış açllarını görmek }\end{array}$ & $\begin{array}{l}\text { Bir zümre başkanı, ayda bir } \\
\text { toplanan zümre çalışma } \\
\text { toplantısında, sınıf yönetimi } \\
\text { teknikleri konusunda çeşitli } \\
\text { araştırma sonuçlarını } \\
\text { paylaşır. Ortaokul } \\
\text { matematik öğretmenleri bir } \\
\text { üniversitenin yaz } \\
\text { enstitüsünde, cebir ve cebir } \\
\text { öğretim teknikleri } \\
\text { konusundaki bilgilerini } \\
\text { geliştirmek için iki haftalık } \\
\text { bir kursa katılırlar. Kursun }\end{array}$ \\
\hline
\end{tabular}


ardından, öğrencilerin kavrayışını sorgulamayla değerlendiren moderatörün, ders süresince kullandığı spesifik öğretim tekniklerini tartışırlar. gözleminden sonra, ders planını, gözleme dayalı elde ettikleri çıkarımlara uyumlu hale getirir ve sonraki derslerini çıkarımları dikkate alarak işlerler.

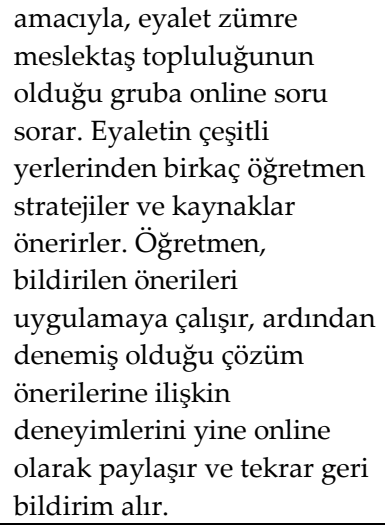

Kaynak: Croft ve diğerlerinden (2010) uyarlanmıştır.

Tablo 1'den görüleceği üzere, işiçinde öğrenmenin üç düzeyi mevcut olup, soldan sağa doğru gidildikçe, MG faaliyetinin sınıf içinde veya okul içinde yürütülme durumuna göre işiçinde oranı düşmektedir. Tablonun en sağında yer alan sütundaki MG faaliyetleri değerli olmakla birlikte, bunlar; öğretmenlerin ders vermekle mükellef oldukları öğrencileri için yürüttükleri öğretim faaliyetlerinin doğrudan odak noktası olmaktan uzak oldukları için, işiçinde faaliyet olarak değerlendirilmemiştir. Bu noktada en etkili ve işiçinde MG faaliyetleri olarak tablonun solundaki sütun olduğunu ifade etmek mümkündür. Zepeda'ya (2017) göre, işiçinde MG yaklaşımlarının yürütülmesi amacıyla öğretmenler için tanımlanan yasal çalışma süreleri içinde zaman kaynağı tahsis edilmelidir. Bu noktada öğretmenin haftalık ders çizelgesinin diğer paydaşlar ile uyumlu hale getirilmesi, derslerin devam ettiği süreçlerde işiçinde MG faaliyetlerine katılan öğretmenin dersinin boş geçmemesi için, mümkün olursa ücret mukabilinde yedek veya gönüllü öğretmenlerin temin edilmesi önem arz etmekte ve faaliyetlerin planlanmasında okul müdürlerine önemli roller düşmektedir.

Mesleki gelişimi etkili kılan işiçinde faaliyetlerden olan ve uluslararası sınavlarda oldukça başarılı olan ülkelerin yanında gelişmiş ülkelerde de oldukça yayın şekilde kullanılan "mentorluk", "meslektaş koçluğu", "araştırma dersi" ve "Şangay araştırma ve ders grupları" yaklaşımları ve bunların benzerlik ve farklılıklar aşağıdaki başlıklar altında tartışılmıştır.

\section{Mentorluk ve Meslektaş Koçluğu Yaklaşımları ve Aralarındaki Farklılıklar}

Mentorluk, meslekte yeni olan aday öğretmenin okulun öznel koşullarına uygun ders planı yapma, buna uygun yöntem ve tekniklerin seçimi, bireysel farklılıkların dikkate alınması, ölçme ve değerlendirmeyi uygun yöntem ve tekniklerle yapabilme, sınıfta etkili ve uygun öğrenme ortamı oluşturmanın yanında özellikle; mesleğin beceri ve sanatsal kısmını ifade eden sınıf yönetimi, öğrenciyi aktif kılma, öğrenci motivasyonunu başlatma ve sürdürmeye yönelik mesleki becerileri ifade eden uygulamalarda makul (kabul edilebilir) bir düzeye gelene kadar tecrübeli ve başarılı bir öğretmenden yakın ve yoğun bir şekilde aldığı destek ve rehberliği ifade etmektedir. TALIS (OECD, 2019, s. 141) mentorluğu, "tecrübeli bir öğretmenin tecrübesi daha düşük bir öğretmene okulda sunduğu destek" şeklinde tanımlamış olup; mentorluk programına (Morgan ve Peter, 2005) okuldaki tüm öğretmenler katılabileceği gibi, sadece aday öğretmenlerin katılabileceği şekilde de yapilandırılabilir.

Mentorluk süreci aday öğretmenlerin mesleki oryantasyonlarında ve mesleğe devam etmelerinde oldukça etkili bir yaklaşımdır. Bu nedenle dünyanın birçok ülkesinde mesleki kariyerinin başında olan öğretmenlerin zorluklarla baş edebilmeleri için mentorluk programlarına katılımları sağlanmakta olup, bu tür programlara katılan öğretmen oranı ABD'de \%90'ın üzerindedir (OECD, 2019). OECD (2019) ülkelerinde mentorluk programı uygulayan okullarda okul müdürlerinin \%77'si meslekte yeni olan öğretmenlerin öğretimini desteklemek için, \%67'si öğretmenin pedagojik yeterliğini ilerletmek için, \%65'i öğretmenlerin meslektaşları ile işbirliğini artırmak için, \%56'sı öğretmenlerin mesleki kimliğini güçlendirmek için, \%54'ü öğrencilerin genel performansını iyileştirmek için ve $\% 42$ ' sinin de öğretmenlerin branşlarına ilişkin bilgilerini genişletmek için mentorluk programının çok önemli olduğunu ifade etmekle birlikte; OECD ülkelerinde eğitimciler üzerinde yapılan tarama araştırmasında, kıdemi beş yılın altında olan öğretmenlerin \%22'si mentorluk 
Öğretmenlerin Mesleki Gelişimi Üzerine...

hizmetine erişim sağlamakta iken; bu oranın ise Türkiye'den katılan öğretmen beyanlarına göre ise \%15 şeklindedir.

Bir çalışmada (Luft ve Cox, 2001) aday öğretmenlerin, oryantasyon programının en değerli bileşeninin mentor ile etkileşime girmek ve ondan geri bildirim almanın yanında, meslektaşları derste gözleme ve onlar tarafından derste gözlenme olduğu belirtilmiştir. Öğretmenlerin sınıflarındaki başarılarında, mentorun etkisine ilişkin değerlendirmeleri ile mentorluk sürecinin kalitesi arasında yüksek düzeyde pozitif ilişkinin yanında; yine öğretmenler tarafından sağlanan mentorluk süresi ile öğrenci başarısı arasında makul düzeyde kanitlar mevcuttur (OECD, 2019).

İşiçinde etkili MG yaklaşımlarından bir diğeri olan meslektaş koçluğu, mesleki deneyimleri ve başarıları birbirine yakın, en az iki veya daha fazla zümre öğretmeninin katılımıyla, katılımcıların sıra ile koçluk rolünü yerine getirmek suretiyle; koç ile öğretmenin ders öncesi görüşme, ders gözlemi ve gözlem sonrası görüşme ve analiz aşamalarını içeren yaklaşımın temel amacı, öğretmenin öğretim becerilerini meslektaş işbirliği / etkileşimi ve desteği yoluyla ilerletmek suretiyle öğrenci başarısını arıtmaktır (Zepeda, Parylo ve Ilgan, 2013). Birkaç karşılaştırmalı araştırmada (Showers ve Joyce, 1996) koçluk hizmeti alan öğretmenlerin, geleneksel MG faaliyetlerine katılanlara oranla, istenen öğretim uygulamalarını daha fazla ve daha uygun şekilde yerine getirdiklerine ilişkin kanıtlar sunulmaktadır.

OECD (2019) ülkelerinde öğretmenler üzerinde yapılan TALIS araştırmasında, öğretmenlerin yarıya yakınının (\%44) meslektaş koçluğu temelli faaliyetlere katılmakla birlikte; ülkeden ülkeye katılım sağlayan öğretmen oranı çok farklılaşmakta olup, Kazakistan, Şangay ve Birleşik Arap Emirlikleri'nde \% 85 'in üzerinde; Finlandiya, Fransa ve İspanya' da ise \%20'nin altında, Türkiye'de ise \%21.5 şeklinde ortaya çımıştır. Türk ve Amerikalı öğretmenler üzerinde yapılan araştırmada ise (Zepeda ve diğerleri, 2013) meslektaş koçluğu bileşeni olarak, Türk öğretmenlerin son bir yıl içerisinde meslektaşlarını derste ortalama olarak 1 defa gözlemekte iken, Amerikalı öğretmenlerin ise meslektaşlarını ortalama olarak 3'ün üzerinde gözledikleri; benzer şekilde Türk öğretmenlerin son bir yıl içerisinde meslektaşları tarafından ortalama olarak 1 defa ders gözlemine maruz kalırken, Amerikalı öğretmenlerin ise 3'ün üzerinde gözleme maruz kaldıkları ortaya çıkmıştır. Koçluk yaklaşımının kullanımına ilişkin istatistiklerin yanında koçluğun etkin şekilde yürütülmesinde okul müdürlerine düşen roller de mevcuttur. Okul müdürü öğretim koçunun rolünü desteklemek suretiyle koçluk programının kolaylaştırıcısı olarak hareket etmiş olur; böylece koçun öğretmenlerle çalışırken ne yaptığını daha geniş kapsamda anlayabilir ve öğretmenlerin koçluk programına katılmak için gerekli zamana sahip olmalarını sağlayabilir (Matsumura, Sartoris, Bickel ve Garnier, 2009).

İşiçinde MG faaliyetleri olan mentorluk ile akran koçluğunun birbirine benzeyen tarafları olmakla birlikte farklılıkları da mevcuttur. Söz edilen iki yaklaşımın farklılıklarını şu şekilde özetlemek mümkündür: Mentorluk sürecindeki taraflardan birisi alan uzmanı, tecrübeli ve başarılı iken, diğeri meslekte yeni veya öğretimde problem yaşayan öğretmen olup; koçlukta ise akademik ve mesleki yetkinlik bakımından birbirine yakın iki akranın birbirinin mesleki gelişimi için yürüttükleri faaliyettir. Koçluk yaklaşımında partnerlerin rolleri, sıklıkla karşılıklı olarak değişmekte iken; mentorlukte ise hizmet veren mentor ile hizmet alan mentinin süreç boyunca rolleri sabittir. Mentorluk süreci, mentinin öğretim becerilerini müstakil bir şekilde derslerini yürütecek düzeye getirinceye kadar devam eden, mentinin performansına göre bir yıldan birkaç yıla kadar sürebilen, uzun soluklu bir zamanı kapsamakta iken; koçluk süreci için bir yarıyıl veya bir öğretim yılı makul bir süre olup, ardından akranların değişimi yoluyla farklı meslektaşların birbirinden istifade etmeleri sağlanır. Mentorluk yaklaşımı mentinin yetkinliğini artırmak amacıyla mentor ile yoğun bir etkileşim ve mesaiyi gerektirmektedir. Bu noktada; mentorluk sürecinin başında mentor ile menti günlük çalışma mesailerinin çoğunluğunu beraber geçirmekte iken, mentinin ilerleme hızına göre zaman içinde beraber geçirilen sürenin yoğunluğu azalmakta, süreç sonlanmadan evvel ise bir arada geçirilen mesainin süresi çeyreğe kadar inmektedir. Koçluk sürecinde partnerlerin etkileşim yoğunluğu mentorluk sürecine göre sinırlı olup, bu noktada partnerlerin etkileşim yoğunluğu haftalık çalışma mesailerinin yaklaşık $1 / 8^{\prime}$ i civarındadır. İki yaklaşım arasındaki diğer bir fark ise, koçluk yaklaşımı sınıf içi öğretim becerilerini geliştirme odaklı yürütülmekte iken; mentorluk süreci ise mentinin sınıf içi öğretim becerilerinin geliştirilmesinin yanında, mentinin okulun sosyal ve kültürel çevresine uyumu, okul kültürünün farkına varılması ve buna uyum 
sağlanması, meslektaşlar ile tanışma ve onlar tarafından benimsenme sürecinin kolaylaştırılması, özetle örgütsel sosyalleşmeyi de kapsayan daha geniş amaçlara hizmet eden bir yaklaşımdır.

\section{Ders Çalışması (Araştırma Dersi) ile Şangay Araştırma ve Ders Takımı}

Ders çalışması, zümre öğretmenlerin öğretim becerilerini geliştirmek amacıyla gönüllü bir öğretmenin örnek ders anlatmadan önce ders planı grup katılımcıları tarafından tartışılır revize edilir. Ders planının müşterek şekilde revize edilmesinin ardından, ders sunulur ve sunulan ders ise grup üyeleri tarafından gözlenir. Son aşamada ise gözlem sonrası tertip edilen toplantıda derse ilişkin analiz ve değerlendirmelerin yapıldığı yaklaşımı ifade etmektedir. Wiburg ve Brown (2006) araştırma dersinin; a) öğretim programı çalışması ve hedeflerin formüle edilmesi, b) ders planı yapılması, c) araştırmanın yürütülmesi ve d) yansıtma yapılması aşamalarından oluştuğunu ifade etmişlerdir. Buna göre döngünün birinci aşaması olan öğretim programı ve hedeflerin formüle edilmesinde öğretmenler, müfredat çalışması sonucunda bulunan ve okulun öğrenme hedefiyle ilgili bir problemi kapsayan bir konuyu tanımlarlar. İkinci döngü olan planlama aşamasında öğretmenler spesifik bir öğrenme problemini ve bu problemin öğrencilerin öğrenme hedeflerini nasıl etkilediğini tanımlar. Planlama amaçlarının formüle edilmesi şu konudaki soruların cevaplanmasıyla sonuçlanabilir (Wiburg ve Brown, 2006): Anlamanın / kavrayışın derinliği veya düzeyi; örneğin: Öğrencilerimizin sahip olmasını istediğimiz kalıcı anlama veya kavrayış nedir? Ölçme yöntemleri, örneğin: Öğrencilerin bu kavrayış veya anlamaya sahip olduklarını nasıl ölçeceğiz? Öğrenme fırsatları, örneğin: Öğrencilerin hedeflenen anlama ve kavrayışlarına ilişkin kazanımlarını desteklemek için hangi öğrenme fırsatları tasarlanabilir? Üçüncü döngüyü, planlanan ders çalışmasının öğretimine ilişkin araştırma yapma aşamasını oluşturmaktadır. Bu dersler bir öğretmen dersi anlatırken, takım üyesi diğer öğretmenlerin ders gözlemi ve gözleme ilişkin veri toplamasını gerektirmektedir. Bu ders, gözlemci öğretmenlerden gelen geri bildirimler ışığında yapılan düzenleme ve revizyonlar kapsamında zamanla tekrarlanabilir. Döngünün son aşamasında takım (zümre öğretmen kurulu olabilir) müşterek şekilde süreç üzerinde yansıtma yapar. Öğretmen takımı, tekrar bir araya gelir, gözlenen ders veya dersler tartışılır ve veriler paylaşılır. İfade edilen bu yansıtma sürecinde veriler; keşfetme, örtük ilgiler ve yeni bilgilerin üretimi için kullanılmalıdır.

Fernandez'e (2002) göre "ders çalışması"nın sıklığına ve temaya öğretmenlerin kendileri karar verirler. Büyük çalışma grupları, sıklıkla 4-6 arası öğretmenden oluşacak şekilde alt gruplara bölünürler. Alt gruplar, aynı amaç kapsamında kendi derslerini planlamakla birlikte, ders planları diğer alt gruplardaki öğretmenlerle paylaşılır, önerileri alınır ve diğer grupların ders gözleminde ve ardından yapılan dersin analizine yönelik tartışmasına katılımları teşvik edilir. Tipik bir ders çalışması için, toplamda 10-15 saat süren grup toplantıları 3-4 haftaya yayılmaktadır. Japonya'da okullarda öğretimin 2:40-3:45 saatleri arasında bitmesinden ve öğrencilerin dağılmasının ardından, meslektaşlarla işbirlikli çalışma ve planlama zamanı sağlaması amacıyla, öğretmenlerin çalışma saati 17:00’ye kadar sürmektedir. Ders çalışması toplantılarının birçoğu öğrencilerin okuldan ayrılmasından sonra yapılmaktadır. Ders çalışması öğretmenlere; bireysel derslerini rafine etmeyi, diğer öğretmenler ile danışmayı ve sınıfta işledikleri derslere ilişkin meslektaş gözlemlerine dayalı olarak geri bildirim almayı, kendi öğretim uygulamalarına ilişkin yansıtma yapmayı, yeni içerik ve yaklaşımlar öğrenmelerini ve sürekli gelişme ile işbirliğini vurgulayan bir kültür geliştirmeye katkı sağlamaktadır (Fernandez, 2002).

Ders çalışmasının benzeri olmakla birlikte kısmen farklı bir yaklaşım olan "Şangay araştırma ve ders takımı"nda öğretmenler ders gruplarında, dersleri planlamak, öğrenci ilerlemesini incelemek ve öğretim içeriğini hazırlamak için beraber çalışırlar. Ders grupları, eğitimde fırsat eşitsizliğiyle mücadelede (Şangay'da eğitimde fırsat eşitliği oldukça yüksek olup PISA sınavında sosyo-ekonomik düzeye göre alt ve üst grup öğrenci başarı farkı batılı ülkelere oranla oldukça düşüktür.) hayati öneme sahiptir. Geride kalan öğrencilere -öğrenme ihtiyaçları yeterince karşılanmamış- hızlıca belirlenip gereken destek sağlanmaktadır. Hem araştırma hem de ders grupları, düzenli ders gözlemlerini, ardından yapılandırılmış geri bildirimi, mesleki öğrenmeyi ve mentorluğa katılımı gerektirmektedir (Liang, Kidwai ve Zhang, 2016). Bu işbirliklerinin, öğrenci öğrenmesi üzerinde etkili olduğunu göstermektedir (Hattie, 2009). Araştırma ve ders grupları öğretmenin haftalık çalışmasının önemli bir unsurudur. Gruplar bazı okullarda haftada bir ile iki saat arasında toplanmakta ve her sömestrde öğretmenler öğrenme ve öğretimi iyileştirmek için altı ile sekiz arasında gözlem 
(gözleyen ve gözlenen) yürütmektedir. Araştırma ve ders gruplarının etkinliğini artırmanın, Şangay'da düşük performanslı çok sayıda okulun, başarı dönüşümünde kritik öneme sahip olduğu belirtilmektedir (Jensen, 2012). Şangay'da araştırma takımları yarıyıl veya bir öğretim yılını kapsayacak şekilde belirledikleri hedeflere yönelik yürüttükleri araştırmaları meslektaşlarına sunar, geri bildirim alır ve bunlardan diğer okullardaki meslektaşlarının da istifade etmesi amacıyla araştırma raporlarını yayınlarlar. Bunun yanında, araştırma takımlarında yer almak kurum kültürünün bir parçası olduğu gibi, öğretmenlerin zümre takımında yer alması yasal zorunluk olmasının yanında; öğretmenlerin yapmış oldukları araştırmaları, hakem denetiminden geçmiş dergilerde yayınlatmış olmaları kariyer basamaklarında yükselmeleri için gerekli koşullar arasındadır (Liang ve diğerleri, 2016).

MG faaliyetlerinin öğretmen kariyer basamaklarıyla ilişkilendirilmesi Şangay'ın dışında Litvanya ve Kazakistan'da da mevcuttur (OECD, 2019). Gürcistan da 2015 yılında çıkarılan Öğretmen İstihdamı, Değerlendirme, Mesleki Gelişim ve Kariyer İlerleme Planı (Teacher Recruitment, Evaluation, Professional Development ve Carrer Advancement Scheme, 2015) kanunu mevcuttur. Bu kanuna göre öğretmen kariyer basamakları; uygulamacı, kıdemli öğretmen, başöğretmen ve mentor öğretmen şeklindeki basamaklardan oluşmuştur. Hizmet içindeki ve aday öğretmenlerin tamamının, kıdemli öğretmen unvanını elde etmek için kariyer sertifikası sınavını kazanmaları gerekmektedir. Öğretmenler kariyer basamaklarında puan kazanmak veya sözleşmenin devamının sağlanması için, zorunlu MG faaliyetlerinin yanında isteğe bağlı olanlara da katılmak durumundadırlar. 2016 yılında yapılan temel bir değişiklikle, zorunlu MG faaliyetleri azaltılmak seçmeli olan faaliyetler ise artırılmak suretiyle, faaliyetlerin öğretmenlerin ilgi ve ihtiyaçlarına hitap etme noktasında esneklik sağlamıştır.

\section{Mesleki Gelişim Faaliyetlerinde Karşılaşılan Zorluklar}

Herhangi bir model, kuram veya yaklaşımın uygulanmasında karşılaşılması olası zorluklar olduğu gibi, MG faaliyetlerini etkili kılma noktasında da çeşitli zorluklarla karşılaşılmakta olup, bunlar aşağıda açıklanmıştır. Mesleki gelişimi etkili kılmaya ilişkin girişimlerin kolay olmadığını ifade etmek mümkündür. Bir okulda etkili olan MG faaliyetinin farklı bir okulda olamaması dolayısıyla, öğretmenler öğretimlerini geliştirmek için farklı destek ve faaliyetlere ihtiyaç duymanın yanında; tüm öğretim, öğrenme ve gelişme faaliyetlerinin günlük yapılan öğretimle entegrasyonunun sağlanması gerekmektedir. MG bağlamında, tüm öğretmenlerin bilmesi, anlaması ve uzmanlaşması için temel ve gerekli öğretim uygulamalarının belirlenmesi konusunda uzlaşı olmaması da, faaliyetlerin yürütülmesinin zorlukları arasında sayılmakta ve bu durumun sonucu olarak da; öğretmenlere yönelik mesleki öğrenme faaliyeti seçen veya tasarlayan yöneticiler için, takip edilmesi gereken en iyi ve en etkili taslak uygulamaları tanımlayan, kolay elde edilebilir kaynaklar ve standartlar sınırlı şekilde mevcuttur (DeMonte, 2013). Ne yazık ki çok sayıdaki mesleki öğrenme faaliyeti, öğretmenin gerçek uygulaması ve okul gelişim planıyla bağlantısı sağlanmadan yürütülmektedir (Cohen ve Hill, 2000).

Hill (2009) kanıtlara dayalı çalışmalarda mesleki gelişimin niteliğini düşüren ve şikâyet konusu olan unsurları şu şekilde ifade etmiştir:

- Genellikle öğretmenin günlük öğretim ve sınıf içi uygulamalarıyla bağlantısı sağlanmamıştır.

- Çok genel olup, öğretim müfredatı veya öğretmenlerin karşılaştığı spesifik öğretim problemleriyle ilişkisi yetersizdir.

- Nadiren yapılmakta olup, bir kez (seminer, çalıştay, konferans vb.) yürütülecek şekilde veya dışarıdan gelen bir danışmanın öncülüğünde yapılan çalıştayın ardından, danışmanın okula veya okul bölgesine bir daha uğranmaması şeklinde uygulanmaktadır.

MG faaliyetlerinin öğretmenlere değerli kazanımlar sağlamasının temel unsurlarında birisinin de onların ihtiyaçlarına hitap eden yaşantılardan oluşmasıdır (Wei ve diğerleri, 2009). OECD (2019) ülkelerinde yapılan araştırmada, öğretmenlerin son bir yıl içerisinde katıldıkları MG faaliyetlerinin öğretmenlerin ihtiyaçları ile yeterince uyumlu olmadığın ifade etmek mümkündür. Örneğin, OECD ülkelerinde ve Türkiye'de "öğretim programı" bilgisine ihtiyaç duyan öğretmen oranı \%10'nun altında olduğu halde, bu konuda katılım sağlanan MG faaliyeti OECD ülkelerinde \%65, Türkiye'de ise \%86 oranında; yine "öğrenci ölçme ve değerlendirme" 
konusunda OECD ülkelerinde eğitime ihtiyaç duyan öğretmen oranı \%13, Türkiye'de ise \%5 olduğu halde; OECD ülkelerinde ve Türkiye' de bu konuda faaliyete katılan öğretmen oranı \%65 şeklinde gerçeklemiştir. Bu istatistikler hem Türkiye hem de OECD ülkelerinde yapılan MG faaliyetlerinin öğretmen ihtiyacından uzak şekilde gerçekleştiği sonucunu ortaya koymaktadır.

Öğretmen görüşlerine göre OECD (2019) ülkelerinde, MG faaliyetlerine katılımı en çok sınırlayan unsurlar; i) MG faaliyetlerinin öğretmenin çalışma saatleri ile çakışması (\% 54.4), ii) MG faaliyetlerine katılım için yeterli teşvikin sağlanmaması (\%47.6) ve iii) MG faaliyetlerinin çok pahalı olması (\%44.6) iken; Türkiye'de ise, i) MG faaliyetlerine katılım için yeterli teşvikin sağlanmaması (\%68.7), MG faaliyetlerinin öğretmenin çalışma saatleri ile çakışması (\% 55.9), işverenin (bakanlık ve il-ilçe milli eğitim müdürlüklerinin) yeterli destek sunmaması (\%55.2), ihtiyaç duyulan MG faaliyetlerinin sunulmaması (\%51.3) ve MG faaliyetlerinin çok pahalı olması (\%41) şeklinde beyan edilmiştir. OECD ülkelerinde ve Türkiye'de öğretmenlerin MG faaliyetlerine katılımı önündeki önemli engellerin başında, ilgili faaliyetlere katılım için tahsis edilmiş zaman olmaması dolayısıyla, faaliyetlerin gerçekleşme zamanı ile öğretmenlerin derslerinin çakışmasıdır. Eğitim sisteminin, öğretmenlere formal (kurs veya seminer gibi) veya informal (meslektaşlarla okul içinde işbirlikli faaliyet yürütme) yetiştirme ve MG faaliyetlerine katılmaları amacıyla mesai saatleri içinde birkaç saat zaman tahsisi sağlamak için çaba göstermelidir (Darling-Hammond, Hyler ve Gardner, 2017). Öğretmen görüşlerine göre, MG faaliyetlerine katılım noktasında "yeterli desteğin sağlanmaması" ve "faaliyetlerin pahalı olması"nın katılımın önündeki engeller oldukları ortaya çıkmıştır. OECD (2019) ülkelerinde öğretmenlerin katılım sağladıkları MG faaliyetlerinin miktarı ile onlara sağlanan destek arasında orta düzeyde pozitif yönlü (r= .59) ilişki hesaplanmış olup; buradan hareketle MG faaliyetlerine katılımın sağlanmasındaki desteğin önemini ortaya koymaktadır. Can (2019) tarafından Türkiye'de yapılan araştırmada, öğretmenlerin MG faaliyetlerine katılımları önündeki engeller arasında; 657 sayılı kanunun garantili istihdam sağlamasının getirdiği rahatlık, eğitim politikalarındaki belirsizlik ve sık değişim, yöneticilerin olumsuz tutumları, ders yükünün fazlalığı, yetersiz motivasyonun yanında mesleki tükenmişliğin varlığı ve okul kültürü ve ikliminin MG faaliyetlerini desteklememesi olduğu ortaya çıkmıştır.

\section{Mesleki Gelişime Katılım Süreleri}

Mesleki gelişimin etkililiğini sağlama noktasındaki temel unsurların başında, bu amaçla yapılan faaliyetlerin süreklilik sağlanması durumunda etkili olduğu (Craft, 2002), kısa süreli veya tek oturum şeklinde yapılan veya kısa süreli seminer, konferans veya çalıştayların sınıf içi öğretim uygulamalarını iyileştirme ve geliştirme bağlamında yeterince etkili olmadığını ifade etmek mümkündür. Hardy (2012) de kısa süreli oturum ve sürelerden oluşan MG faaliyetlerinin birçok öğretmen için "kusurlu veya eksik" biçiminde öğrenme sağladığını ifade etmektedir. Hirsh ve Ponder (1991; akt. Zepeda, 2017) tek bir çalıştay şeklinde yürütülen MG faaliyetinde öğretmenlerin yazlınca \%10'unun, yeni öğrendikleri becerileri günlük öğretim uygulamalarına aktarabildiklerini belirtmişlerdir. Mesleki gelişimin süresine ilişkin olarak şu çıkarımda bulunmak mümkündür: MG faaliyetleri, öğretmenin mesleki yaşamının ve rutin olarak yaptığ öğretim işinin bir parçası olmasını sağlamak amacıyla, bu tür faaliyetleri okul kültürü ve yaşamının olağan ve ayrılmaz bir parçası haline getirmek ve bunu kolaylaştırmak için yasal ve kültürel normları değiştirmenin yanında, yasal çalışma süresi içinde tanımlanan zaman tahsisi sağlamak önem arz etmektedir. Bu başlık altında Türkiye ve dünya ülkelerinde öğretmenlerin katıldığı MG faaliyetlerinin türü ve süresine değinilmiştir.

OECD (2019) ülkelerinde yapılan tarama çalışmasında öğretmenlerin \%94'ünün okul müdürlerinin ise \%99'unun, son bir yıl içerisinde en az bir adet MG faaliyetine katılmak suretiyle, eğitimcilerin mesleki yaşamları bakımından olumlu bir farkındalık ve motivasyona sahip olduklarını ifade etmek mümkündür. OECD ülkelerinde MG faaliyetlerine katılımın zorunlu olup olmaması bakımından, Litvanya ve Kazakistan hem öğretmenlik sözleşmesinin yenilenmesi hem de maaş ve kariyer basamakları için mesleki gelişimi zorunlu kılan iki ülke olarak dikkat çekmekle birlikte, yasal zorunluk MG faaliyetlerine katılımı güvence altına almanın tek yolu değildir. Örneğin, Singapur'da yasal zorunluluk olmamasına rağmen, MG faaliyetlerine çok yüksek düzeyde katılım sağlanan ülkelerin başında gelmektedir. Bunun muhtemel sebepleri arasında, mesleki gelişimin okulun mesleki öğrenmeye ilişkin paylaşılan vizyonunun içine yerleşmiş olmasıdır. Öğretmenlere mesleki gelişimleri için rehberlik ve öğretmen ağlarına erişim desteğiyle birlikte yıllık 100 saat yetiştirmeye 
yönelik yatırım yapılmaktadır. Sonuç olarak MG faaliyetleri, Singapurlu öğretmenler için sözleşme uzatma veya kariyer basamağından daha fazlası olup, faaliyetler öğretmenlerin günlük iş ve okul görevlerinin bir parçasıdır.

ABD'de 55.000 öğretmenin katıldığı ulusal çapta bir araştırmada (Choy ve diğerleri, 2006) mesleki kıdemi 3 yıl ve altında olan öğretmenlerin, kıdemi 10 yıl ve üzerinde olanlara oranla MG faaliyetlerine daha fazla katılma eğiliminde oldukları ve branşlarında daha fazla oranda üniversitelerden kurs aldıkları; daha büyük okul bölgelerinde görev yapan öğretmenlerin ise, daha küçük bölgelerde görev yapanlara oranla, daha çeşitli kurslara katılma şansı elde ettikleri ortaya çıkmıştır. OECD (2019) ülkelerinde de 13 ülkeden 6'sında ilköğretim öğretmenlerinin ortaöğretim öğretmenlerine oranla MG faaliyetlerine daha fazla katılma eğiliminde oldukları ortaya çıkmıştır. Türkiye'de yapılan bir araştırmada (Yağmur, 2019), ilkokul öğretmenlerinin ortaöğretim öğretmenlerine oranla koçluk temelli MG faaliyetlerini daha az yürütmekle birlikte, ilkokul öğretmenlerinin ortaokul ve meslek lisesi öğretmenlerine oranla daha fazla sayıda MG faaliyetine katıldıkları ortaya çıkmıştır. Bunun yanında bireyselleştirilmiş MG faaliyetlerine, mesleki kıdemi 21 yıl ve üzerinde olan öğretmenlerin, kıdemi daha düşük olanlara oranla; MG faaliyetlerine katılım süresi bakımından ise mesleki kıdemi 3-5 yıl arasında olanların, kıdemi 21 yıl ve üzerinde olanlara oranla, daha fazla katıldıkları ortaya çıkmıştır. MEB'in (2019a) 2018 yılına ilişkin faaliyet raporunda bakanlık merkez teşkilatı ve yerel düzeyde yürütülen 35.374 faaliyete, bir milyonun üzerinde katılımın yanında öğretmen başına ortalama 38 saat süreli hizmet içi eğitim faaliyeti yürütülmüştür. Tablo 2' de TALIS araştırmasına katılan öğretmenlerin OECD (2019) ülkelerinde ve Türkiye' de katıldıkları MG faaliyetlerinin türleri ve süresine ilişkin istatistikler verilmiştir.

Tablo 2

OECD Ülkelerinde ve Türkiye'de Öğretmenlerin Katıldıkları MG Faaliyetlerinin Türleri ve Süresine İlişkin İstatistikler

\begin{tabular}{lcc}
\hline Mesleki Gelişim Faaliyeti & $\begin{array}{c}\text { OECD } \\
\text { Ülkeleri }\end{array}$ & $\begin{array}{c}\text { Türkiye (15.498 } \\
\text { Öğretmen) }\end{array}$ \\
\hline 1) Son bir yıl içerisinde katılım sağlanan MG faaliyetinin miktarı (adet) & 4 & 4.3 \\
2) Kurs ve seminere katılım oranı & 75.6 & 86 \\
3) Online kurs ve seminere katılım oranı & 35.7 & 46.3 \\
4) Yapılmış bir araştırmayı sunmak üzere veya eğitim alanında tartışmaların yapıldı̆̆ı & 48.8 & 51.8 \\
konferanslara katılım oranı & & \\
5) Lisansüstü programlar gibi, uzun erimli ve geniş kapsamlı nitelik kazandırmaya yönelik & 14.5 & 33.4 \\
programlara katılım oranı & 55.1 & 25.6 \\
6) Diğer okullara gözlem ziyareti yapma oranı & 17.4 & 19 \\
7) Kamu kurumu, sivil toplum ve diğer işyerlerini gözlem ziyareti yapma oranı & 43.9 & 21.5 \\
8) Formal okul yapısının bir unsuru olarak, meslektaşı derste gözleme, kayıt cihazıyla kendi & 39.9 & 43.1 \\
dersini gözleme ve koçluk faaliyetine katılım oranı & 72.3 \\
9) Mesleki gelişim amaçlı oluşturulan öğretmen ağına katılım oranı & 33.3 \\
10) Mesleki alanyazın okuma oranı & 69.2 \\
11) Diğer mesleki gelişim faaliyetlerine katılım oranı & 37.2 \\
\hline
\end{tabular}

Tablo 2'den görüleceği üzere, son bir yıl içerisinde Türkiye ve OECD ülkelerindeki öğretmenlerin MG faaliyetlerine katılımlarının kurs ve seminer çalışmalarına katılım, eğitim alanındaki konferanslara katılım, diğer okullar ve sivil toplum örgütü ziyaretleri, MG amaçlı online ağlara katılım, mesleki alanyazın okuma bakımından benzer oldukları ortaya çıkmıştır. Diğer yandan Türk öğretmenlerin OECD ülkelerindeki meslektaşlarına oranla, lisansüstü gibi uzun erimli programlara devam etme bakımından daha fazla katılım sağlamakta iken; meslektaş koçluğu temelli ders gözlemleri ve diğer okul ziyaretlerini ise daha az yaptıkları ortaya çıkmıştır. Yukarıdaki tartışmalar ışığında MG faaliyetlerini etkili kılan unsurlar bağlamında Türk eğitim sistem için yapılan çıkarımlar aşağıda tartışılmıştır.

\section{Türk Eğitim Sistemi için Öğretmenlerin Mesleki Gelişimine Yönelik Tartışma ve Çıkarımlar}

Bu başlık altında etkili mesleki gelişim sisteminin kurulması amacıyla destekleyici bazı unsurlara ilişkin çıarımların ardından, mesleki gelişimi etkili kılan unsurlara yönelik Türk eğitim sistemi için çıkarım ve tartışmalar yapılmıştır. 


\section{Mesleki Gelişimi Destekleyici Unsurlar}

1) Öğretmen adaylarının hizmet öncesi eğitim kurumlarına seçiminde, yaşıtları arasında yetenekli ve kamu hizmeti motivasyonu ile gençleri ve toplumu bilinçlendirme ülküsü olanlar tercih edilmeli (OECD, 2019; Perry ve Wise, 1990) ve mümkünse eğitim süresince burs desteği (Jensen, 2012) vermesi önerilir.

Yetenekli gençlerin öğretmenlik mesleğine çekilmesi, mesleğin geleceği ve kamuoyu nezdindeki saygınlığını ciddi anlamda artıran bir unsur olacaktır. Mevcut durumda, eğitim fakültesine yerleşenlerin yanı sıra, öğretmenlik mesleğine kaynak teşkil eden fen-edebiyat türü fakültelere yerleşen öğrencilerin akranları arasında üniversiteye yerleşme puanları veya yüzdelik dilimlerinin olması gerekenden uzak olduğu ifade edilebilir. Bu durumun ortaya çıkmasında eğitim fakültesi ve öğretmenlik mesleğine kaynak teşkil eden diğer fakülte öğrenci sayısının olağanın çok üstünde olmasının yanında, Pedagojik Formasyon Eğitimi Sertifika Programlarının (PFESP) sınırsız şekilde isteyen herkese verilmesinin büyük etkisi olduğunu ifade etmek mümkündür. Bu noktada eğitim fakültesine girişte ilgili puan türünde 300 bininci olarak belirlenmiş sıralamanın, daha da aşağı çekilmesi ve PFESP'nin de sadece öğretmen olacaklara hizmet içi eğitim yoluyla verilmesine yönelik düzenlemeler yapılabilir. Nitekim Millî Eğitim Bakanlığı Talim ve Terbiye Kurulunun 29 Haziran 2020 tarih ve 12 sayılı kararında (2020) yükseköğretim kurumları tarafından sertifika düzeyinde yürütülen pedagojik formasyon sertifika eğitiminin geçerliğini yitirdiği ifade edilmiştir. Bunun yanında eğitim fakültesine yerleşenlere verilecek ilave bursun, yetenekli gençlerin mesleğe girişine katkı sağlayacaktır. Yine eğitim fakültesine yerleşmede, toplumu bilinçlendirme ülküsüne sahip olanların eğitim fakültesine alınması, değerli bir uygulama olarak görünmekle birlikte, merkezi sınavlarla buna yönelik geçerli ve güvenilir ölçüm yapmanın zorluklarından dolayı, mevcut sınav sisteminde bu ilkenin uygulanabilirliği zor görünmektedir.

2) OECD (2019) ülkelerinde lisansüstü eğitime sahip öğretmen oranı \%45.5 iken; Türkiye'de ise bu oranın 2018 yılı istatistiklerine göre \%9 (MEB, 2019b) düzeyinde olduğu ortaya çıkmıştır. Günümüzde öğretim faaliyetlerinin karmaşık bir duruma dönüşmüş olması, eğitim sistemi ve öğretmen üzerinde artan kamuoyu beklentisinin karşılanabilmesi için, öğretmenlerin lisansüstü eğitimi teşvik edilmelidir.

Kalkınmış ve uluslararası sınavlarda başarılı ülkelerde lisansüstü eğitime sahip öğretmen oranı gittikçe artmakta, ülkemizde ise bu oranın düşük olmasının yanı sıra, artış oranının da düşük olduğunu ifade etmek mümkündür. Günümüzün karmaşık ve zorluklarla dolu dünyasında, öğretmenlerin lisansüstü eğitim yapmalarını teşvik edilmesi ve bu noktada büyük potansiyele sahip eğitim fakülteleri, hizmet öncesi eğitim yerine hizmet içi eğitime odaklanabilirler. Türkiye'de 115 eğitim / eğitim bilimleri fakültesinde 6546 öğretim üyesi (Yükseköğretim Kurulu [YÖK], 2019), öğretime yönelik mesailerinin birçoğunu, sayısı 200 binin üzerinde olan eğitim fakültesi öğrencisini yetiştirmenin yanı sıra, buna ilave bir yük olarak, fakültelere kaynak temin etmesi dolayısıyla açılmakta olan PFESP'ler için mesai harcamak yerine; öğretmenlerin lisansüstü programlar yoluyla mesleki gelişimlerini sağlamaya yönelik harcamalarını sağlamaya yönelik yapısal düzenlemeler önerilebilir.

3) Öğretmenlerin hizmet öncesi eğitimi nitelikli de olsa, kuramsal ağırlıklı olup mesleğin başlangıcında başarılı bir performans için gereken yetkinlikleri sağlamaktan uzaktır (Musset, 2010; OECD, 2005); bu noktada aday ve mesleki kariyerinin başındaki öğretmenlere başarılı ve tecrübeli öğretmenlerden oluşan mentorlerin, mentorluk hizmeti vermesi (Jensen, 2012; Wei ve diğerleri, 2009; Zepeda, 2015) önerilir.

PISA sınavlarında yüksek performans gösteren ülkelerin yanı sıra gelişmiş ülkelerde de mentorluk oldukça yayın bir uygulama olup; öğretmen adayı havuzunun daraldığı gelişmiş ülkelerde öğretmenlerin mesleğe uyumlarını kolaylaştırmakta ve öğretmenlerin mesleğe devamına katkı sağlamaktadır. Ülkemizde aday öğretmenlere mentorluk benzeri bir uygulama olan rehber öğretmen ataması yapılmakla birlikte, işlevsel şekilde uygulandığını söylemek zordur. Öneri olarak, mentor adayları belirlendikten sonra, bunlara verilecek eğitimin ardından alacakları sertifika ile mentor olmaları ve öğretmen adayları ile adaylıkları süresince yoğun bir etkileşim içinde olmalarını sağlamak suretiyle, aday öğretmenlerin mesleki oryantasyonları kolaylaştırılabilir. 
4) MG faaliyetlerinde, ihtiyaç duyulan zamanın sağlanması ile öğretmenlerin teşvik edilmesinde (Jensen ve Farmer, 2013); öğrendikleri fikir ve stratejileri sınıflarına uygulamalarını sağlamak için gereken destek ve teşvikte (Desimone ve Garet, 2015); öğretmenin haftalık ders çizelgesinin MG faaliyetlerine katılımı kolaylaştıracak şekilde planlanmasında (OECD, 2019) okul liderliğinin desteğine ihtiyaç vardır.

Okul müdürü / liderliği okulun akademik başarısında oldukça önemli bir role sahiptir. Bu noktada okul müdürü öğretmenlerin ulusal ve yerel düzeydeki faaliyetlerin MG faaliyetlerine katılımını teşvik etmenin yanı sıra, son derece etkili olan okul gününde ve işiçindeki MG faaliyetlerini yaygınlaştırmak için gerekli düzenlemeleri yapmalıdır. Okul akademik yaşamı yeni, özgün ve farklı yaklaşımların ve hipotezlerin test edildiği, denemelerin yapıldığı, tartışmaların yürütüldüğü, fikir alışverişlerinin yapıldığ ; özetle öğrenmenin ve mesleki ilerlemenin okul yaşamının bir parçası olduğu okul kültürünün oluşturulmasında okul müdürü son derece önemli bir role sahiptir.

5) Mentor ve Öğretim Koçlarına (ÖK) rehberlik hizmetine başlamadan önce hizmet içi eğitim verilmelidir (Wei ve diğerleri, 2009; Zepeda, 2015).

Mentor ve ÖK'ler, yetkinliğe sahip olanlar arasından, bilişsel ve uygulamalı sınavlar sonucunda seçilmelerinin ardından, uygulama ağırlıklı alacakları hizmet içi eğitimin sonucunda başarılı olmak suretiyle alacakları sertifikaya dayalı olarak mentor ve ÖK şeklinde görevlendirirler. ÖK'lerin ağırlıklı olarak öğretim konusunda problem yaşayanlara ve yeni yaklaşımların sınıfa uygulanması hususundaki örnek uygulama ve atölye çalışmalarını yürütmesi, mentorlerin ise ağırlıklı olarak aday öğretmenlerin mesleki oryantasyonlarının sağlanmasına ilişkin rolleri yerine getirecekleri varsayımından hareketle, mentor ve ÖK'lere verilecek hizmet içi eğitimin buna göre kısmen farklılaşması gerektiği dikkate alınmalıdır.

6) Tecrübeli ve başarılı öğretmenlerden oluşan mentor ve ÖK'lerin, ihtiyaç duyan öğretmenlere yönelik yapacakları görev ve rolleri tanımlayan ve bu kapsamda ücret, ek ders ve kariyer basamaklarında yükselmelerine yönelik yönetmelik düzenlenmelidir. Mili Eğitim Temel Kanunu ve Devlet Memurları Kanununda Değişiklik Yapılmasına İlişkin 5204 sayılı Kanun (2004), kapsamında, 1739 sayılı Milli Eğitim Temel Kanununda yapılan değişiklikle öğretmenlik mesleğinde kariyer basamakları oluşturulmakla birlikte; getirilmiş olan bu düzenleme halihazırda işlevsiz konumdadır. Tecrübeli ve başarılı öğretmenlere yönelik getirilecek Mentorluk ve ÖK'lik bir tür kariyer basamağı gibi düşünüldügüunde, işlevsiz haldeki kariyer basamaklarını kısmen telafi etmenin yanında, mesleki kıdemi ilerlemiş ve kısmen mesleki yorgunluğa sahip öğretmenlerin mesleki motivasyonlarını artırma potansiyeline de sahiptir.

7) MG faaliyetlerine katılan meslektaşlar arasında güven ilişkisi sağlanmalıdır (Bryk, Camburn ve Louis, 1999). Mentorluk, koçluk, eylem araştırması, araştırma dersleri işiçinde ve işbirlikli şekilde yürütülen oldukça etkili MG faaliyetleri olmakla birlikte, bunların etkin şekilde yürütülmesi için, öğretmenler arasında güven ilişkisi sağlanmalıdır. Özellikle öğretmen performansının değerlendirilmesi ile MG faaliyetlerinin birbirinden ayrılması gerekmekte olup, MG faaliyetlerinde elde edilen verilerin performans değerlendirmesinden ayrılmasına özen gösterilmesi önerilir. Aksi takdirde, gönüllülük esasına göre yürütülmesi gereken MG faaliyetlerine öğretmen katılımını sağlamakta zorluklar yaşanması olasıdır.

8) Öğretmenlerin meslektaşlarla yürütecekleri işbirlikli çalışmaların etkili olması için çatışma çözme, problem çözme stratejileri, uzlaşı sağlanması ve diğer toplantı becerilerinin geliştirilmelidir (Hord ve diğerleri, 1998). 21. yüzyılın işgücü becerileri arasında yer alan takımın üyesi olarak etkili çalışma konusunda, öğretmenlerin becerilerinin geliştirilmesi önem arz etmektedir. Okullarda, öğretmenlerin işbirliği içinde çalışma becerilerinin ilerletilmesi için öğretmenlere uygulamalı eğitimler verilmesi uygun olacaktır.

9) Ücretli MG faaliyetlerine katılmak için öğretmenlere maddi destek sağlanmalıdır (OECD, 2019). Kongre, sempozyum, etkili iletişim, beden dili, hızlı okuma, kişisel gelişim gibi faaliyetlerden ücretsiz olanların yanında ücretli faaliyetler de mevcut olup, öğretmenlerin ücreti faaliyetlere katılımları maddi olarak desteklenebilir. Türkiye'de yapılan bir araştırmada (Yağmur, 2019) öğretmenlerin yarıdan fazlasının MG faaliyetleri için kişisel bütçelerinden aylık 50 TL ve üzerinde, makul bir miktarda, para harcadıkları ortaya çıkmıştır. 
10) Öğretimin devam ettiği zaman dilimlerinde yürütülen MG faaliyetlerinde öğretmenlerin ders saatlerinde gerçekleşen faaliyetlere katılımlarını sağlayabilmek ve derslerin boş geçmemesi için, ücret mukabilinde yedek veya gönüllü öğretmen tahsisi sağlanması önerilir (Zepeda, 2017). Okullarda yedek veya gönüllü öğretmen yalnızca MG faaliyetleri için değil, hastalık veya mazeret dolayısıyla derslerine devam edemeyen öğretmenlerin derslerinin boş geçmemesi için de büyük önem arz etmektedir. Öğretmenin MG faaliyetlerine katılımı önemli olmakla birlikte, faaliyetlere katıldığı zaman dilimlerinde derslerinin boş geçmesi makul bir durum değildir. Türkiye'de, özellikle lisans düzeyinde eğitime sahip olan genç işsiz sayısının çokluğunun yanında, öğretmen olmak için yasal koşulları sahip yarım milyona yakın öğretmen adayı havuzu olduğu dikkate alındığında, okullarda yedek veya gönüllü öğretmen bulmanın kolay olduğu sonucuna ulaşmak mümkündür. Bunun yanında ders karşılığı ücret alan, 657 sayılı kanuna tabi olmayan, öğretmenlere verilen ücretin düşüklüğü dikkate alındığında, okullarda ücret mukabilinde yedek veya gönüllü öğretmen bulundurmanın maliyetinin karşılanabilir olduğu ifade edilebilir.

11) Öğretmenlerin MG kapsamında yapacakları faaliyetler, öğretmen portfolyo dosyasında saklanmalıdır. Bu kapsamda öğretmen, yıl boyunca yaptığı MG faaliyetlerine ilişkin özet raporu, elde ettiği kazanımları ve yansımalarını içeren notlarını mesleki dergilerde (Jensen, 2012) paylaşmalıdır. Öğretmenlerin her öğretim yılının başında, eylül ayındaki seminer çalışmaları esnasında, bireysel MG planı yapmaları önerilir. Öğretmenlerin, bu planlar kapsamında yıl boyunca yürüttükleri / katıldıkları MG faaliyetlerine ilişkin yazılı, görsel ve sesli materyalleri kapsayan kanıtları belgelendirmeleri ve bunları meslektaşlarına katkı sunmak üzere paylaşmaları ve kariyer basamağında kullanması önerilmektedir.

12) Aday öğretmenlik süresinin, daha nitelikli bir yetiştirme sağlaması amacıyla, 2 yıla çıarılması önerilmektedir. Öğretmen adaylarının adaylık süresi, diğer birçok memuriyet türünde olduğu gibi bir yıldan az iki yıldan fazla olamamaktadır. Aday devlet memurlarının kahir ekseriyeti, öğretmen adayları da dahil olmak üzere, kolaylıkla asli devlet memurluğuna geçiş yapabilmektedir. Adaylık sürecinin, şüphesiz diğer meslekler de önemli olmakla birlikte, özellikle öğretmenlik mesleğinde, uygun olmayan adayların mesleğe geçişte bariyer olarak varlığı önem arz etmektedir. Adaylık sürecinde, adayın kendi yapacağı özdeğerlendirmesi yoluyla mesleğe uygun olmadığına ilişkin kararının yanı sıra, performans ve psikolojik özellikler bakımından, mesleğe uygun olmayan adayların diğer kamu kurumlarında istihdamının sağlanması yoluyla mesleğe geçişleri engellenebilir. Bu noktada doğru karar verebilmek için, adaylık sürecinin bir yıl yerine iki yıla çıkarılması, meslekte devam edecek olanlar ile ayrılacak olanları ayırması bakımından (Gujarati, 2012; İlğan, 2014) önerilmektedir. Mesleki anlamda performans veya kişilik yönünden gerekli nitelikleri karşılamayan birinin, asaleten öğretmenliğe atanması suretiyle, on yıllarca ders vereceği öğrencilerinin üst sinıfa ve kademelere eksik formasyon ile geçmelerine yol açabilecektir. Bu durum, öğrencinin nitelikli eğitim alma hakkının ihlaline yol açacaktır. Bunun önüne geçmek için, adaylık sürecinin iki yıla çıarılmasının yanında geçerli ve güvenilir ölçümler yoluyla mesleğe uygun olan ve olmayanların belirlenmesi mümkün olabilecektir.

\section{Mesleki Gelişimi Etkili Kılan Özellikleri ve Çıkarımlar}

1) MG kısa süreli, çalıştay, seminer, konferans şeklinde değil süreğen şekilde devamlılık arz etmelidir (Craft, 2002; Garet ve diğerleri, 2001; Hiçbir Çocuğun Geride Bırakılmaması Kanunu, 2002; OECD, 2019; Saxe, Gearheart ve Nasir, 2001). Bu kapsamda MG faaliyetlerinin yıllık 30, mümkünse 49, saatin üzerinde ve bir öğretim yılı içerisinde yılın en az altı ayına yayılacak şekilde sürekliliği sağlanmalıdır (Archibald ve diğerleri, 2011; Yoon ve diğerleri, 2007).

Türkiye'de öğretmenlere yönelik, ulusal düzeyde MEB'in, yerel düzeyde ise il, ilçe ve okullarda çok çeşitli ve sayıda MG faaliyetleri yürütülmesinin yanında, haziran ayında derslerin bitiminden temmuz ayının başına kadar geçen süre ile eylül ayının başı ile öğretimin başladığı süredeki yaklaşık 20 iş günü MG için tahsis edilmiştir. Haziran ve eylül aylarındaki seminer çalışmaları olarak bilinen MG faaliyetleri, oldukça uygun ve etkili bir zaman tahsisi sağlamakla birlikte, bu sürenin etkili şekilde kullanıldığını ifade etmek zordur (Yağmur, 2019). Yine Yağmur tarafından yapılan araştırmada, bir öğretim yılını içerecek şekilde, haziran ve eylül aylarında seminer için ayrılan sürede öğretmenlerin \%77'sinin fiili olarak 10 saat ve altında MG 
faaliyetleri yürüttükleri ortaya çıkmıştır. 20 günlük iş takvimi içerisinde 10 akademik çalışma saati süresinin yeterli olmadığını, bunun artırılması gerektiği sonucuna ulaşmak mümkündür.

2) İşiçinde yapılan MG faaliyetlerinin etkili, kalıcı, ekonomik ve öğrenci öğrenmesi üzerinde olumlu etkileri olması dolayısıyla, yürütülen faaliyetlerin çoğunluğunun bunlardan oluşması sağlanmalıdır (Garet ve diğerleri, 2001; Hawley ve Valli, 1999; Opfer ve Pedder, 2011; Wei ve diğerleri, 2009; Zepeda, 2015). Öğretmenin yansıtıcı uygulamacı olarak okulda günlük öğretim işini icra ederken, aynı zamanda mesleki gelişimini sağlaması oldukça etkili ve işe yarar bir yaklaşımdır. Bu noktada genellikle bir oturumdan oluşan ve öğretmene uygulama yapma imkânı sağlamayan seminer, konferans ve panellerin öğretmenlerim mesleki gelişimine katkısının sınırlı olduğundan hareketle, faaliyetlerin işiçinde olması büyük önem arz etmektedir. MG faaliyetlerinin sürekliliğinin sağlanması ancak günlük öğretim işinin içine yerleştirilmesi ile mümkündür. Türkiye'de öğretmenlerin işiçine yerleştirilmiş MG faaliyetlerinden olan sınıf içi gözlem ve ziyaretleri betimleyen meslektaş koçluğu faaliyetleri (Zepeda ve diğerleri, 2013) ve önceki maddede vurgulandığı üzere, seminer çalışmalarında fiilen yapılan MG faaliyetleri için yeterli süre ayrılmadığı (Yağmur, 2019; Zepeda ve diğerleri, 2013) sonucuna ulaşmak mümkündür. Bu noktada özellikle haziran ve eylül aylarında seminer için ayrılmış zaman dilimlerinde şu faaliyetlerin yapılması suretiyle MG faaliyetlerine katılım süresi artırılıp etkililiği sağlanabilir: a) Öğretmen eğitim alanında okumuş olduğu güncel bir kitaptan elde etmiş olduğu çıkarımları meslektaşlarıyla paylaşır. b) Öğretmen meslektaşlarına önceden planladığı bir konuda örnek bir ders sunumu yapar ve meslektaşlarından derse ilişkin geri bildirim alır. c) Yıl boyunca eylem araştırması yürütmüş olan öğretmen, buna ilişkin deneyimini ve çıkarımlarını meslektaşlarıyla paylaşır. d) Okul içinde veya dışında tamamlanmış veya devam eden bir projenin paydaşı olan öğretmen projenin amacı, önemi ve bittiyse çıktıları hakkında meslektaşlarına paylaşımda bulunur. e) Zümre öğretmen takımları, haziran ayında öğretim yılı boyunca yürütülen eğitim-öğretim faaliyetlerinin değerlendirilmesi ve akademik başarının artırılması; eylül ayında ise merkezi olarak belirlenmiş öğretim programını okul / sınıf seviyesine uyumu konusunda takım üyeleriyle tartışmak, görüş alışverişimde bulunmak ve kararlar vermek üzere bir araya gelirler. f) Mentorluk hizmeti alan aday öğretmen (menti) ve hizmet veren mentor sürece ilişkin deneyimlerini paylaşırlar. g) Meslektaş koçluğu faaliyetine katılan öğretmen, sürecin değerlendirilmesi ve elde edilen kazanımlara ilişkin meslektaşlarına paylaşımda bulunur.

3) MG faaliyetlerini yürütmek için, yeterli zamana ihtiyaç duyulmakta; bu kapsamda faaliyetler için yasal çalışma saatleri içerisinde zaman tahsisi sağlanması önerilir (Garet ve diğerleri, 2001; Hawley ve Valli, 1999; Van Hook, Lee, Ferguson, 2010; Wei ve diğerleri, 2009; Zepeda, 2017). Profesyonel meslek sahipleri, 21. yüzyılın mesleki anlamda zorlayıcı koşullar ve rekabet gerektirdiğinin farkında olup; bu zorlukların üstesinden gelmek için yaşam boyu öğreniciler olduklarını bilir ve mesleklerini yürüttükleri süre boyunca mesleki yetkinliklerini ilerletecek faaliyetlere katılırlar. Bu noktada öğretmenlerin bir kısmı, özel yaşamlarına ait zamanlardan fedakârlık yapmak suretiyle, mesai saatlerinin dışında, gönüllü şekilde formal veya informal MG faaliyetlerine katılmakla birlikte; bu durumu tüm öğretmenler için yasal ve zorunlu hale getirmek olası olamayacağı için, öğretmenlerin MG faaliyetlerine katılımını sağlamak için mesai saatleri içerisinde zaman tahsisi sağlanması uygun bir yaklaşım olacaktır.

4) MG faaliyetleri meslektaş katılımını ve işbirlikli faaliyetleri kapsamalı (Barber ve Mourshed, 2007; Darling-Hammond ve diğerleri, 2017; DeMonte, 2013; Garet ve diğerleri, 2001; Harwell, D'Amico, Stein ve Gatti, 2000; Opfer ve Pedder, 2011; Saxe ve diğerleri, 2001); planlama ve yürütme süreçlerinde öğretmenlerin katılımını sağlamalıdır (Bransford ve diğerleri, 2001; Garet ve diğerleri, 2001; Stephens ve Boldt, 2004; Wei ve diğerleri, 2009; Zepeda, 2015).

Öğretmenlerin yürütecekleri MG faaliyetlerini etkili kılan unsurların başında, planlama aşamasında öğretmenlerin katılımının sağlanması ve faaliyetlerin uygulanmasında meslektaşların bir araya gelmek suretiyle işbirliği yapmalarının sağlanması gelmektedir. Buna göre temel bir yönetim ilkesi olarak, paydaşların karar alma süreçlerine katılımı sağlandığı takdirde, alınan kararların uygulanma olasılığının artmasının yanında, faaliyetlerin öğretmen ihtiyaçlarını karşılama olasılığı da artacaktır. Bunun yanında, meslektaşlar arasında güven ikliminin tesis edilmesi koşuluyla, paydaşların bir araya gelmeleri ve beraber çalışmalarını sağlamanın, onların mesleki gelişimine önemli katkılar sunacaktır. Türkiye'de öğretmenlerin 
kendileriyle ilgili konularda alınan kararlara katılımlarının yeterli şekilde sağlandığını söylemek zordur. Kararlar ağırlıklı olarak, bakanlık merkez teşkilatınca alınmakta ve taşra teşkilatlarının da ilgili kararları okullara aktarması beklenmektedir. Bu noktada merkeziyetçi yönetim yapısının, karar alma süreçlerinde paydaş katılımını sınırlayan bir duruma yol açtığı sonucuna ulaşmak mümkündür.

5) MG faaliyetleri, koçluk, mentorluk, eylem araştırması ve ders çalışması gibi öğretmenleri aktif kılacak öğrenme yaşantılarını içermelidir (OECD, 2019; Opfer ve Pedder, 2011; Zepeda, 2015). Temel bir öğrenme ilkesi olarak, katılımcıları aktif / faal kılan yaşantıların kalıcılığı, diğer faaliyetlere oranla daha fazladır. Buradan hareketle, öğretim mesleğinin hem uygulamalı olması sebebiyle hem de uygulamalı öğretim faaliyetlerinin kalıcılığının daha fazla olması dolayısıyla, öğretmenler için tasarlanan MG faaliyetlerinin uygulama ve öğretmeni aktif kılacak yaşantılar içermesi önem arz etmektedir. Buradan hareketle, öğretmen katılımının ve uygulamanın sınırlı olduğu seminer ve konferans yerine öğretmen katılımını sağlayan, meslektaş koçluğu, mentorluk, eylem araştırması, proje yürütme, farklı okul ve sınıf ziyaretleri gibi faaliyetler tercih edilmelidir.

6) $M G$, öğretmenin sahip olduğu bilgi ve becerilerin üzerine inşa edilmelidir (Bransford ve diğerleri, 2001; DeMonte, 2013; Hiçbir Çocuğun Geride Bırakılmaması Kanunu, 2002; Zepeda, 2015). Yetişkinler MG faaliyetlerine, ylllarca elde ettikleri tecrübe ve bunun üzerine inşa ettikleri çeşitli ilke, varayım ve genellemeler ile katılırlar. Bu noktada yetişkin ve aynı zamanda profesyonel olan öğretmenlerin katıldığı MG faaliyetlerinde sahip oldukları bilgi birikimi ve yıllar içerisinde elde etmiş oldukları birikim dikkate alınmak suretiyle planlama yapılması önem arz etmektedir.

7) MG faaliyetlerinin tasarımında öğretmenin ihtiyaçları dikkate alınmalıdır (Desimone ve Garet, 2015; Wei ve diğerleri, 2009; Zepeda, 2015). Öğrenim düzeyi ve öğrencilerinin sosyo-kültürel düzeyi birbirinden çok farklı okullarda, farklı branş ve deneyime sahip öğretmenler için MG faaliyetlerinin de çeşitlendirilmesi ihtiyaçları vardır. Türkiye'nin coğrafi olarak görece büyük olmasının yanında, sosyal ve kültürel yönden de oldukça zengin ve binlerce yıllık bir tarihe sahiptir. Okulöncesi ile ortaöğretim düzeyinde 18 milyon öğrenci ve 1.119.446 öğretmen (MEB, 2019b) mevcuttur. Bu çeşitliliğin yanında ortaöğretim okullarında özellikle mesleki ve teknik eğitim kurumlarında çok sayıda farklı okul türü mevcuttur. Coğrafi büyüklük ve kültürel çeşitlik / zenginliğin yanında, öğrenci ve öğretmen sayısı ile okul türü ve çeşitliği dikkate alındığında, MG faaliyetlerinin bu çeşitliği yansıtması amacıyla; öğretmen, öğrenci ve okulun öznel ihtiyaçları dikkate alınarak planlanması önem arz etmektedir. Daha özelde öğretmenlerin branşlarının, mesleki kıdemlerinin, performanslarının, öğretimde yaşadıkları problemlerin, profesyonellik düzeylerinin, çalıştıkları okul türü ve okuldaki öğrenci profili ile öğrencilerin hazırbulunuşluk düzeylerinin birbirinden farklı olması dolayısıyla; öğretmenler MG noktasında farklı içerik, konu ve sürelere ihtiyaç duyarlar (İlğan, 2017). MG faaliyetlerinin planlanmasında, bu farklılık ve çeşitliğin dikkate alınması, öğretmenler için daha etkili sonuçlar üretme potansiyeline sahiptir. Önceki kısımda vurgulandığı üzere, Türkiye'de merkeziyetçi yönetim yapısı nedeniyle kararların çoğunluğunun bakanlık merkez teşkilatında alınması dolayısıyla, MG planlamasına ilişkin kararlarda bölge, il, ilçe ve okul düzeyinde öğretmen ihtiyacının uygun şekilde gözetilmesinin oldukça düşük bir olasılık olduğu belirtilebilir. Belirtilen nedenlerden dolayı MG amacıyla, bakanlık merkez teşkilatının planlayacağı ve yürüteceği faaliyetlerin yanı sıra; il, ilçe ve okul düzeylerinde de ilgili organlara bütçe ve karar alma salahiyetinin tanınması önerilmektedir.

8) MG faaliyetleri, branş bilgisi ile alana özgü öğretim yöntem ve tekniklerini içeren ve bu bilgileri sınıfına nasıl uyarlayacağı ve kullanacağına ilişkin uygulamaları kapsamalıdır (Desimone ve Garet, 2015; Garet ve diğerleri, 2001; Opfer ve Pedder, 2011; Saxe ve diğerleri, 2001; Wei ve diğerleri, 2009). MG faaliyetlerinin yürütülmesinde alana özgü öğretim yöntem ve tekniklerinin dikkate alınması amacıyla, tüm branşların dahil olabileceği tartışma platformlarının yanında, alana özgü etkinlikleri de kapsaması ve bunların sınıf içi uygulama ve atölye çalışmalarını içerecek şekilde yürütülmesi önerilmektedir.

\section{Yazar(lar)ın Beyanı}

Araştırmacıların katkı oranı beyanı: Makalenin tamamı yazar tarafından kaleme alınmıştır. 
Etik Kurul Kararı: Bu makale derleme niteliğinde olup, Türk eğitim sistemi için tartışma ve çıkarımlar yapılmıştır. Bu kapsamda insan veya hayvanlar üzerinde deney veya veri toplama işlemi yapılmadığı için, etik onay alınmasını gerektiren bir husus mevcut değildir.

Çatışma beyanı: Bu çalışma kapsamında herhangi bir kişi, kurum ya da kuruluşla çıkar çatışması bulunmamaktadır.

Destek ve teşekkür: Araştırmanın yürütülmesinde herhangi bir kurumdan destek alınmamıştır.

\section{Kaynaklar}

Allensworth, E., Ponisciak, S. ve Mazzeo, C. (2009). The schools' teachers leave: Teacher mobility in Chicago public schools, consortium on Chicago school research. Erişim adresi: https://consortium.uchicago.edu/publications/schools-teachers-leave-teacher-mobility-chicago-publicschools

Archibald, S., Coggshall, J. G., Croft, A. ve Goe, L. (2011). High-quality professional development for all teachers: Effectively allocating resources. Research \& Policy Brief. National Comprehensive Center for the Teacher Quality.

Avalos, B. (2011). Teacher professional development in teaching and teacher education over ten years. Teaching and Teacher Education, 27(1), 10-20. doi: 10.1016/j.tate.2010.08.007

Barber, M. ve Mourshed, M. (2007). How the world's best performing school systems come out on top. New York: McKinsey \& Company.

Blandford, S. (2001). Professional development in schools. F. Banks ve S. Mayes. (Ed.), Early professional development for eachers (s. 12-19) içinde. London: David Fulton Publishers.

Bransford, J., Brown, A. ve Cocking, R. (2001). How people learn: Brain, mind, experience, and school. Washington DC.: National Academy Press.

Bryk, A., Camburn, E. ve Louis, K. (1999). Professional community in Chicago elementary schools: Facilitating factors and organizational consequences. Educational Administration Quarterly, 35(5), 751-781.

Can, E. (2019). Öğretmenlerin meslekî gelişimleri: Engeller ve öneriler. Eğitimde Nitel Araştırmalar Dergisi Journal of Qualitative Research in Education, 7(4), 1618-1650. doi:10.14689/Issn.2148-2624.1.7c.4s.14m

Choy, S., Chen, X. ve Bugarin, R. (2006). Teacher professional development in 1999-2000: What teachers, principals, and district staff report. National Center for Education Statistics, Washington, DC. Erişim adresi: https://nces.ed.gov/pubs2006/2006305.pdf.

Coggshall, J. G. ve Ott, A. (2010). Retaining teacher talent: Convergence and contradictions in teachers' perceptions of policy reform ideas. Naperville, IL: Learning Point Associates and New York: Public Agenda.

Cohen, D. K. ve Hill, H. C. (2000). Instructional policy and classroom performance: The mathematics reform in California. Teachers College Record, 102(2), 294-343.

Craft, A. (2002). Continuing professional development: A practical guide for teachers and schools. NY: Routledge, Taylor \& Francis Group.

Croft, A., Coggshall, J., Dolan, M. ve Powers, E. (2010). Job-embedded professional development: What it is, who is responsible, and how to get it done well (Issue Brief). Washington, DC: National Comprehensive Center for Teacher Quality. Erişim adresi: https://learningforward.org/wp-content/uploads/2017/08/job-embeddedprofessional-development.pdf

Cropanzano, R. (2009). Writing non-empirical article for journal of management: general thoughts and suggestions. Journal of Management, 35(6), 1304-1311. doi: 10.1177/0149206309344118

Darling-Hammond, L. (2000). Teacher quality and student achievement: A review of state policy evidence. Education Policy Analysis Archives, 8(1), 1-44. 
Darling-Hammond, L., Hyler, M. ve Gardner, M. (2017). Effective teacher professional development, learning. Policy Institute, Palo Alto, CA. Erişim adresi: https://learningpolicyinstitute.org/sites/default/files/productfiles/Effective_Teacher_Professional_Development_REPORT.pdf

DeMonte, J. (2013). High quality professional development for teachers: Supporting teacher training and to improve student learning. Centers for American Progress. Erişim adresi: https://cdn.americanprogress.org/wpcontent/uploads/2013/07/DeMonteLearning4Teachers-1.pdf

Desimone, L. M. ve Garet, M. S. (2015). Best practices in teachers' professional development in the United States. Psychology, Society, E Education, 7(3), 252-263.

Easton, L. B. (2008). From professional development to professional learning. Phi Delta Kappan, 89(10), 755-759.

Fernandez, C. (2002). Learning from Japanese approaches to professional development: The case of lesson study. Journal of Teacher Education, 53(5), 393-405.

Fuller, R. B. (1982). Critical path. NY: St. Martina's Press.

Garet, M. S., Porter, A. C., Desimone, L., Birman, B. F. ve Yoon, K. S. (2001). What makes professional development effective? Results from a national sample of teachers. American Educational Research Journal, 38(4), 915-945.

Gujarati, J. (2012). A comprehensive induction system: A key to the retention of highly qualified teachers. The Educational Reform, 76(2), 218-223. doi:10.1080/00131725.2011.652293

Guskey, T. R. (2003). Analyzing the lists of characteristics of effective professional development to promote visionary leadership. NASSP Bulletin, 87(637), 4-20.

Hardy, I. (2012). The politics of teacher professional development: Policy, research and practice. NY: Routledge, Taylor \& Francis Group.

Harwell, M., D'Amico, L., Stein, M. K. ve Gatti, G. (2000, February). Professional development and the achievement gap in Community School District \#2. Annual meeting of the American Educational Research Association sunulan bildiri, New Orleans, LA.

Hattie, J. (2009). Visible learning: A synthesis of over 800 meta-analyses relating to achievement. Abingdon, Oxon: Routledge.

Hawley, W. D. ve Valli, L. (1999). The essentials of effective professional development: A new consensus. L. Darling-Hammond ve G. Sykes (Ed.), Teaching as the learning profession: Handbook of policy and practice (s. 127-150) içinde. San Francisco: Jossey-Bass.

Hiçbir Çocuğun Geride Bırakılmaması Kanunu. (2002). Erişim Adresi: https://www.govinfo.gov/content/pkg/PLAW-107publ110/pdf/PLAW-107publ110.pdf

Hill, H. C. (2009). Fixing teacher professional development. Phi Delta Kappan, 90(20), 470-476. Erişim Adresi: http://www.pdkmembers.org/members_online/publications/Archive/pdf/k0903hil.pdf

Hord, S. M., Rutherford, W. L., Huling-Austin, L. ve Hall, G. E. (1998). Taking charge of change. Austin, Texas: Southwest Educational Development Laboratory.

İlğan, A. (2014). Öğrencinin akademik başarısını etkileyen öğretmen karakteristikleri. İ. Aydın ve K. Yılmaz (Ed.) Prof. Dr. Haydar Taymaz armağan kitabı (s. 367-391) içinde. Ankara: Pegem Akademi.

İlğan, A. (2017). Öğretmenlerin mesleki gelişimi ve denetimi. Ankara: Anı Yayıncılık.

Jensen, B. (2012). Catching up: Learning from the best school systems in East Asia. Summary Report. Victoria, Australia: Grattan Institute. Erişim adresi: https://grattan.edu.au/wpcontent/uploads/2014/04/129_report_learning_from_the_best_main.pdf 
Jensen, B. ve Farmer, J. (2013). School turnaround in Shanghai: The empowered management approach to improving school performance. Washington: Center for American Progress. Erişim adresi: https://cdn.americanprogress.org/wp-content/uploads/2013/05/ShanghaiReport-INTRO.pdf

Knapp, M. (2003). Professional development as a policy pathway. Review of Research in Education, 27, 109-157.

Liang, X., Kidwai, H. ve Zhang, M. (2016). How Shanghai does it: Insights and lessons from the highest-ranking education system in the world, directions and development. Washington DC: World Bank.

Luft, J. A. ve Cox, W. E. (2001). Investing in our future: A survey of support offered to beginning secondary science and mathematics teachers. Science Educator, 10(1), 1-9.

Matsumura, L. C., Sartoris, M., Bickel, D. D. ve Garnier, H. E. (2009). Leadership for literacy coaching: The principal's role in launching a new coaching program. Educational Administration Quarterly, 45(5), 655693.

Milli Eğitim Bakanlığı. (2019a). Milli Ĕ̆itim Bakanlığı 2018 yılı faaliyet raporu. Erişim adresi: http://sgb.meb.gov.tr/meb_iys_dosyalar/2019_03/01175437_MillY_EYitim_BakanlYY_2018_YYlY_Ydare _Faaliyet_Raporu_YayYn2.pdf

Millî Eğitim Bakanlığı, Strateji Geliştirme Başkanlığı. (2019b). Milli eğitim istatistikleri, örgün eğitim, 2018-2019. Ankara: Millî Eğitim Bakanlığı Yayınları.

Millî Eğitim Bakanlığı, Talim ve Terbiye Kurulu. (2020). Geçmişten günümüze kurul kararları ve fihristleri. Erişim adresi: https://ttkb.meb.gov.tr/www/gecmisten-gunumuze-kurul-kararlari/icerik/152

Mili Eğitim Temel Kanunu ve Devlet Memurları Kanununda Değişiklik Yapılmasına İlişkin Kanun (2004, 8 Temmuz). Resmi Gazete (Sayı 25516). Erişim adresi: https://www.resmigazete.gov.tr/eskiler/2004/07/20040708.htm\#1

Musset, P. (2010). Initial teacher education and continuing training policies in a comparative perspective: Current practices in OECD countries and a literature review on potential effects. OECD Education Working Papers 48. OECD Publishing, Paris.

Morgan, C. ve Peter, N. (2005). Continuing professional development for teachers: From induction to senior management. NY: Routledge, Taylor \& Francis Group.

Opfer, V. ve D. Pedder. (2011). Conceptualizing teacher professional learning. Review of Educational Research, 81(3), 376-407. doi:10.3102/0034654311413609.

Organisation for Economic Co-operation and Development. (2005). Teachers matter: Attracting, developing and retaining effective teachers, education and training policy. Paris: OECD Publishing. doi:10.1787/9789264018044-en.

Organisation for Economic Co-operation and Development. (2014). Indicator D7: How extensive are professional development activities for teachers?Education at a Glance 2014: OECD Indicators içinde. Paris: OECD Publishing. doi: 10.1787/888933120461

Organisation for Economic Co-operation and Development. (2019). TALIS 2018 results (Volume I): Teachers and school leaders as lifelong learners. Paris: OECD Publishing. doi:10.1787/1d0bc92a-en

Özkan, U. B. (2019). Matematik ve fen başarısının belirleyicisi olarak öğretmenlerin eğitim düzeyi. Anemon Muş Alparslan Üniversitesi Sosyal Bilimler Dergisi, 7(6), 29-43.

Özkan, U. B. (2020). Almanya ve Türkiye'deki ilkokul öğretmenlerinin mesleki gelişim faaliyetlerine katılımının öğrencilerin matematik ve fen başarısına etkisi. Cumhuriyet Uluslararası Eğitim Dergisi, 9(1), 243-269.

Perry, J. ve Wise. L. (1990). The motivational bases of public service. Public Administration Review, 50(3), 367373. 
Perry, J., Hondeghem, A. ve Wise, L. (2010). Revisiting the motivational bases of public service: Twenty years of research and an agenda for the future. Public Administration Review, 70(5), 681-690. doi:10.1111/j.15406210.2010.02196.x.

Rosenberg, M. (2017). Marc my words: Coming knowledge tsunami. 18 Mart 2020 tarihinde https://learningsolutionsmag.com/articles/2468/marc-my-words-the-coming-knowledge-tsunami adresinden erişildi.

Saxe, G., Gearhart, M. ve Nasir, N. S. (2001). Enhancing students' understanding of mathematics: A study of three contrasting approaches to professional support. Journal of Mathematics Teacher Education, 4, 55-79.

Scribner, J. (1999). Professional development: Untangling the influence of work context on teacher learning. Educational Administration Quarterly, 35(2) 238-266. doi: 10.1177/0013161X99352004.

Showers, B. ve Joyce, B. (1996). The evolution of peer coaching. Educational Leadership, 53(6), 12-16.

Song, S., Hur, E. ve Kwon, B. (2018). Does high-quality professional development make a difference? Evidence from TIMSS. Compare: A Journal of Comparative and International Education, 48(6), 954-972. doi:10.1080/03057925.2017.137333

Stephens, D. ve Boldt, G. (2004). School university partnerships: rhetoric, reality, and intimacy. Phi Delta Kappan, 9(85), 703-707.

Teacher Recruitment, Evaluation, Professional Development ve Carrer Advancement Scheme. (2015). Decree of the Government of Georgia no. 68: Initiating teacher activities, approving professional development and career progression scheme, Chapter V. Erişim adresi: https://matsne.gov.ge/document/view/2739007?publication=0

Timperley, H., Wilson, A., Barrar, H. ve Fung, I. (2007). Teacher professional learning and development: Best Evidence Synthesis Iteration [BES]. Wellington, New Zealand: Ministry of Education. Erişim adresi: http://educationcounts.edcentre.govt.nz/goto/BES

Van Hook, K., Lee, D. ve Ferguson, S. (2010). Voices from the field: Teachers describe their experience with a bold system of reform. Santa Monica, CA: National Institute for Excellence in Teaching.

Wei, R. C., Darling-Hammond, L., Andree, A., Richardson, N. ve Orphanos, S. (2009). Professional Learning in the learning profession: A status report on teacher development in the United States and Abroad. Technical Report. ABD: National Staff Development Council. Erişim adresi: https://edpolicy.stanford.edu/sites/default/files/publications/professional-learning-learning-professionstatus-report-teacher-development-us-and-abroad.pdf

Wiburg, K.M. ve Brown, S. (2006). Lesson study communities: Increasing achievement with diverse students. Thousand Oaks, CA: Corwin Press.

Yağmur, B. (2019). Öğretmenlerin mesleki gelişim faaliyetlerine katıllmlarn ile iş doyumları arasındaki ilişki (Yayımlanmamış yüksek lisans tezi). Düzce Üniversitesi, Sosyal Bilimler Enstitüsü, Düzce.

Yoon, K. S., Duncan, T., Lee, S. W. Y., Scarloss, B. ve Shapley, K. L. (2007). Reviewing the evidence on how teacher professional development affects student achievement (Issues \& Answers Report, REL 2007-No. 033). Erişim adresi: https://ies.ed.gov/ncee/edlabs/regions/southwest/pdf/REL_2007033.pdf

Yükseköğretim Kurulu Başkanlığı. (2019). istatistik.yok.gov.tr. Erişim Tarihi: 12.05.2020.

Zepeda, S. J. (2015). Job embedded professional development: Support, collaboration, and learning in schools. NY: Routledge, Taylor \& Francis Group.

Zepeda, S. J. (2017). Instructional supervision: Applying tools and concepts. NY: Routledge, Taylor \& Francis Group.

Zepeda, S. J., Parylo, O. ve Ilgan, A. (2013). Teacher peer coaching in Amerikan and Turkish schools. International Journal of Mentoring and Coaching in Education, 2(1), 64-82. doi:10.1108/20466851311323096 
Öğretmenlerin Mesleki Gelişimi Üzerine...

\section{EXTENDED ABSTRACT}

\section{Introduction}

Professional development (PD) has typically seen as traditional approach to in-service when asked to teachers to implement new curriculum or other reform initiatives. However, nowadays, it is seen as a principal part of professional life. Education systems provide formal and informal many different kinds of PD opportunities for teachers such as graduate programs, course, seminar, workshop, mentoring, peer coaching, action research, research lesson, virtual network, social media, professional literacy, visiting different class and schools. However, some of these opportunities are more effective under certain conditions.

Zepeda (2019) define effective PD activities as job-embedded where the work of teaching and learning how to teach, to improve, and to meet the needs of students coalesce into opportunities to see live the impact of efforts on student learning. Effective PD activities should be based on adult learning principals that support the connections between the need for learning, actual learning, and the experiences involved in learning. Craft (2002) indicated that effective PD activities should place a greater emphasis on the evidence of existing practice and thus targeted training, move towards a broader view of what in-service training and PD are, focus on ensuring that school and individual needs are addressed through PD activities, evaluate the effect of PD activities and increasing interest in seeing initial teacher training, induction and PD as continuous PD activities. On the other hand, Morgan and Peter (2005) suggest effective PD activities should include as followed: Tailored for the individual teacher, self-directed and mentoring and observation, activities were targeted, focused to whole-school, included feedback and support along with funding and finally was ongoing process.

\section{Method}

This non-empirical theory article (Cropanzano, 2009) based on current literature review related to effective PD opportunities included such as mentoring, coaching, Japanese lesson study and Shanghai research and lesson groups to create implications for Turkish education system along with environment will support PD in schools. The data collected via document analyses based on literature review are expected to generate implications and conclusions. The authentic contribution of this paper could be defined as follows: Creating system along with organization environment will support PD opportunities and implications for Turkish education system related with effective PD facilities included conclusion in terms of Turkish context. The implications and results obtained as a result of this study are detailed below.

\section{Results and Implications}

The implications and conclusions obtained as a result of this study and detailed in this chapter can be seen as a contribution of this study to the field of educational administration and to practitioners including policymakers and decision-makers of educational organizations.

- Applications and selection to faculty of educations suggested to based on talent among peers and having consciousness ideal for society (OECD, 2190; Perry and Wise, 1990). Additionally to this certificate programs for teaching profession should be terminated. Talented and qualified graders demanded to be teacher should be provided teaching certificate after induction via in-service training.

- The number of teachers with a master's degree is quite high in developed countries that are successful in international tests. This rate is $9 \%$ among Turkish teachers, which is far less than that in developed countries. There are 115 faculty of education as a constitution of universities along with 6546 faculties have Ph. D. degree as a human force in Turkey to increase education level of teaching forces.

- Even though prospective teachers receive high-quality training at the university, it is advisable to assign a mentor for each novice teacher. This is because pre-service training, which predominantly consists of a theoretical curriculum, lacks practices that allow prospective teachers to gain work experience in schools.

- Regulations should include a clear definition of mentoring and instructional coaching (Wei et al., 2009; Zepeda, 2015) before assigning experienced teachers as mentors or instructional coaches. Mentoring and 
instructional coaching is not available as formal body of Turkish education context that novice and experienced teachers have teaching problems could benefit potentially from this body.

- Some PD opportunities for teachers are delivered for a free. Teachers willing to participate in these PD activities should be receive reimbursement from their schools.

- Teachers wishing to participate in PD opportunities should be provided with extra free time. Zepeda (2017) suggested substitute or volunteer teachers could be employed as a substitute for permanent teachers who want to participate in PD. Hundreds of thousands of nominees for teaching position were available in Turkey that easy to recruit substitutes affordably which some of them already working in schools as part-time teaching position.

- Effective PD activities should last longer than one-session conferences, workshops, panels, symposiums, or seminars. Such activities can be delivered throughout a whole academic year (Craft, 2002; Garet et al., 2001; Hiçbir Çocuğun Geride Bırakılmaması Kanunu, 2002; OECD, 2019; Saxe et al., 2001). In conclusion, PD opportunity for teachers should be more than 30 hours, and if possible, more than 49 , throughout an academic year. Evidence shows that PD activities delivered for teachers more than 30 hours in a year raises student achievement significantly.

- Job-embedded learning as an effective PD opportunity which occur during daily work of teachers suggested to use in Turkish education system as an easy, practical and cost-efficient approaches included coaching, mentoring and lesson study.

- Effective PD activities require teachers to collaborate, discuss, share, and learn from each other (Barber and Mourshed, 2007; Darling-Hammond et al., 2017; DeMonte, 2013; Garet et al., 2001; Harwell, et al., 2000; Opfer ve Pedder, 2011; Saxe et al., 2001). Therefore, bringing teachers together provides a valuable professional development chance for them and helps them to enhance their teaching repertoire.

- Effective PD opportunities should consider teachers' needs. Turkey has a quite young population, with 18 million K-12 students along with more than 1.1 million teachers. Additionally, Turkey is a geographically huge and culturally rich country. Bringing all these together with diversity of Tukey, PD activities should fulfil teachers need. 